


\section{PRINCIPAL AUTHOR}

GRAEME L. WORBOYS is Co-Vice-Chair, Connectivity Conservation and Mountains, International Union for Conservation of Nature World Commission on Protected Areas and an Adjunct Fellow at the Fenner School, The Australian National University.

\section{ACKNOWLEDGMENTS}

Appreciation is expressed to Sue Feary, Penny Figgis, Emeritus Professor Larry Hamilton, Ashish Kothari, Michael Lockwood and Emeritus Professor Adrian Phillips who contributed importantly to the content and development of early versions of this chapter. Appreciation is expressed to Ashish Kothari for his contributions to the ICCA sections of the Chapter.

\section{CITATION}

Worboys, G. L. (2015) 'Concept, purpose and challenges', in G. L. Worboys, M. Lockwood, A. Kothari, S. Feary and I. Pulsford (eds) Protected Area Governance and Management, pp. 9-42, ANU Press, Canberra.

\section{TITLE PAGE PHOTO}

Gray Lake Glacier, Torres del Paine National Park, Chile Source: Eduard Müller 


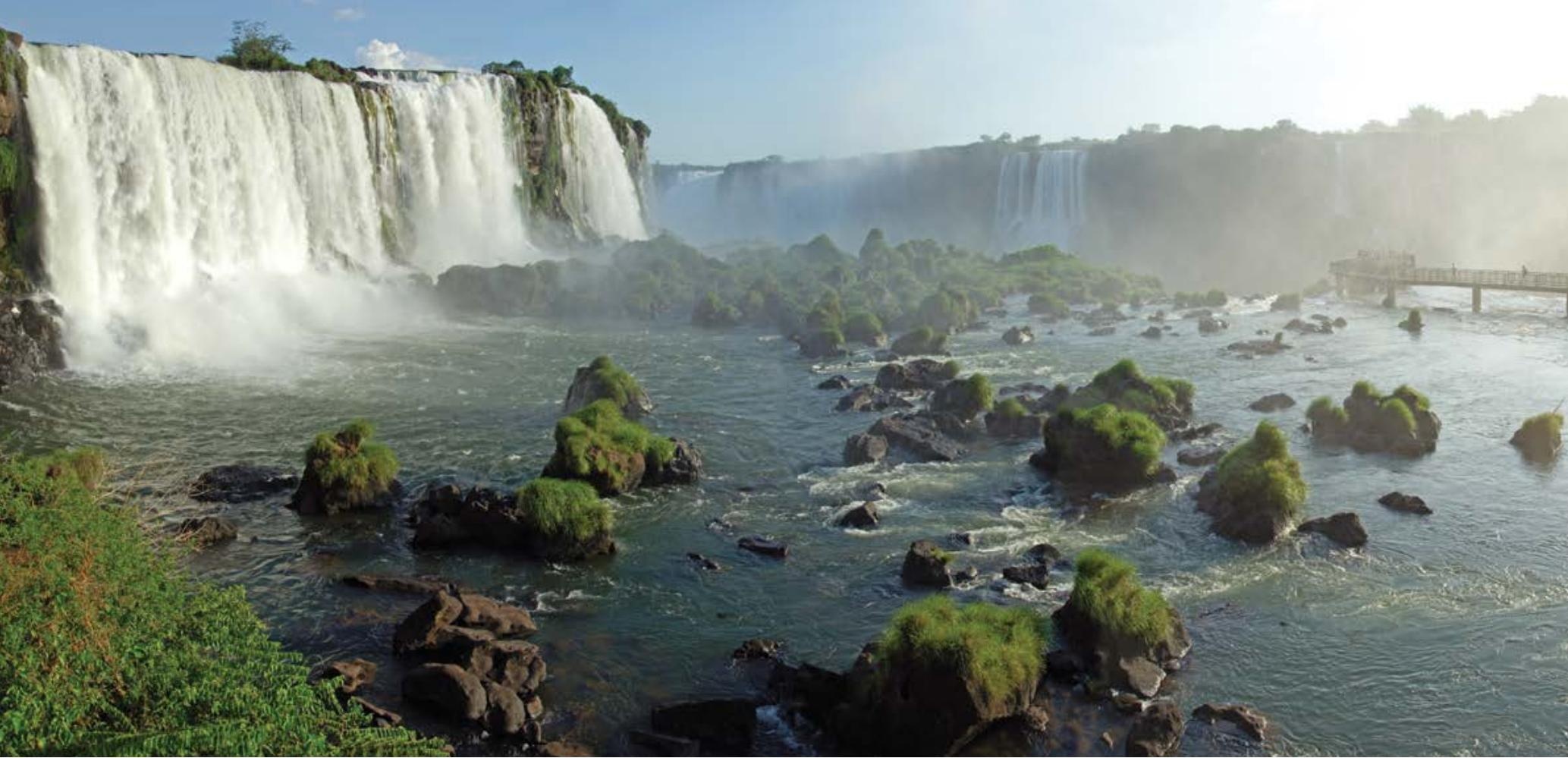

Iguazu Falls, Iguazu National Park, Brazil

Source: Eduard Müller

\section{Introduction}

Protected areas are the places where we aim to retain the extraordinary beauty and richness of the Earth and all its benefits to humanity - the evolutionary heritage of more than four billion years and for all we know unique in the vastness of the universe. They may include grand scenery; remarkable animals and plants; precipitous mountains; spectacular formation-rich caves; grand towering forests; dramatic plunging waterfalls; immense wetlands and lakes; vast deserts; and untouched coastlines, deep ocean mounts and expansive coral reefs. They can also hold landscapes of great beauty and cultural values, created by human communities over time and through traditional management practices.

Nations are proud of their protected areas and they are valued, loved and visited by people from all over the world. Protected areas are critical for maintaining healthy ecosystems and a healthy environment for people and all other species. They are essential for biodiversity conservation; they deliver clean water and air; they are vital to the cultures and livelihoods of traditional and indigenous communities for sustainable sustenance; they bring sustainable development benefits to millions of people through nature-based tourism; and they are a critical natural solution for climate change. They are also important for their rich history and the cultural associations they conserve including grand historical sites, and their special cultural landscapes, features and sites of spiritual, social and historical significance to a nation's peoples. They are typically protected, in perpetuity, by a nation's strongest laws.
In this chapter, we introduce important protected area concepts, including the definition of protected areas, protected area categories, governance and their management. Geographic areas that contribute to conservation other than protected areas are also introduced. The majority of IUCN protected area capacity development information developed since 1947 has been identified and listed in an annexure of this chapter to provide a single source list to assist readers and researchers.

\section{Concept and purpose}

Protected areas and their establishment and professional management are particularly a 20th and 21 st-century phenomenon, but it could surprise many that the concept of protected areas has existed for tens of thousands of years. Very old protected areas may still be found, including some where religious devotion has helped to conserve natural environments. The island of Itsukushima near Hiroshima, Japan, for example, has been a shrine to Shintoism since the 6th century and the island's sacred natural forests have been protected for their intrinsic values and for providing replacement timbers for the shrine's wooden structures (Stolton 2010). An even earlier example is Mount Kailas in Tibet, which was mentioned as a holy mountain in the 4th century BC, and is revered and protected by Buddhist, Hindu, Jain and Bon adherents, making it the world's most sacred mountain (Bernbaum 1990). In many other areas, communities have managed their activities to conserve the ecosystems that sustain them. 


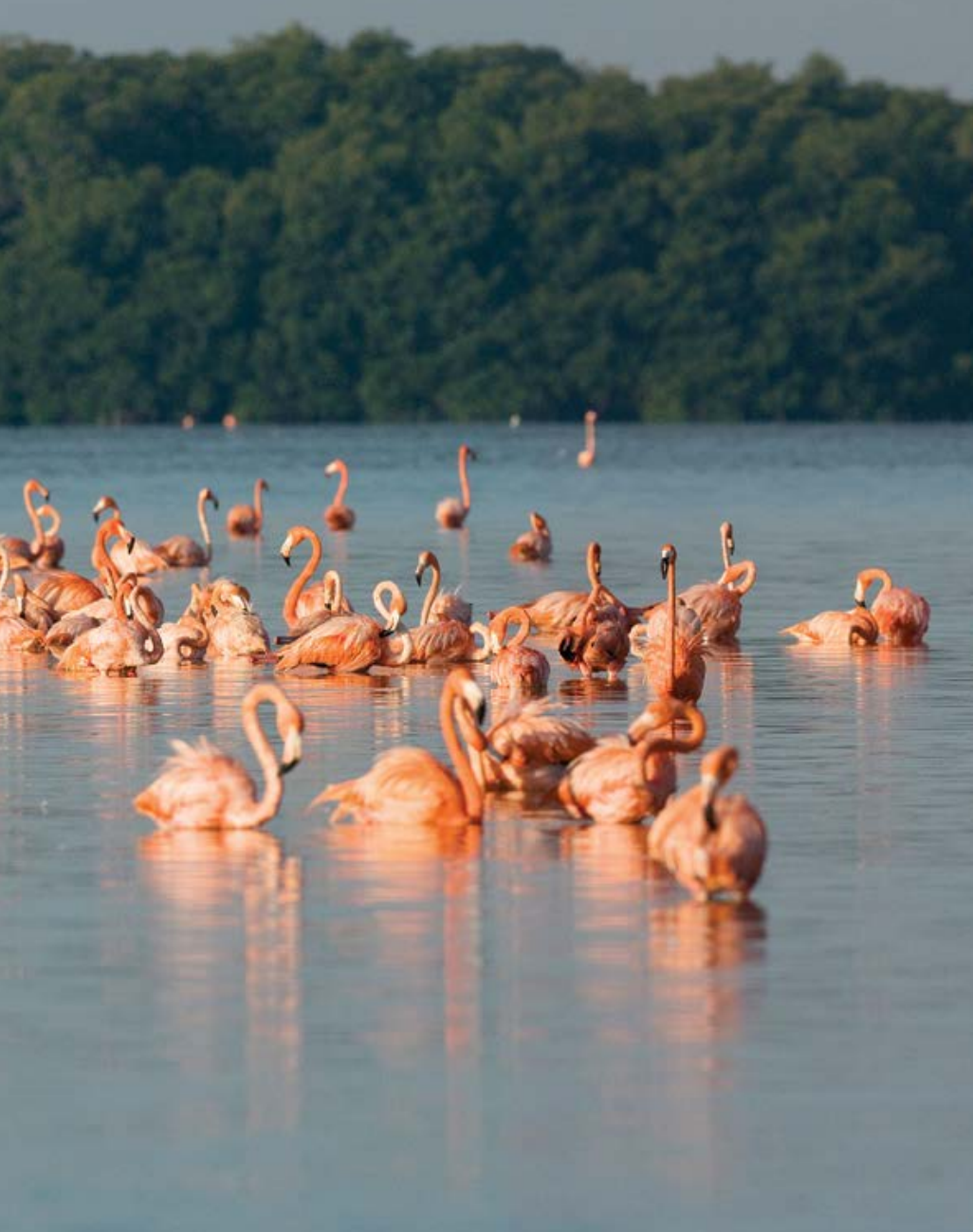

Flamingos, Panorama, Celestún National Park, Mexico

Source: Eduard Müller

In a British colony on the other side of the world, Australia, there was also emergent conservation thinking. The importance of Bunya pine (Araucaria bidwillii) to Indigenous Australians was recognised by Governor Gipps of the Colony of New South Wales when, in 1842, he issued a special decree that no timber licences be issued for any rainforest north of Brisbane that contained this species (Worboys et al. 2005). It was a conservation edict that respected the values and needs of Aboriginal Australians. In 1866, the Jenolan Caves Reserve in New South Wales was established by law to protect outstanding limestone caves from vandalism (Finlayson and Hamilton-Smith 2003). In 2014, this same Jenolan Caves Reserve formed part of the Greater Blue Mountains World Heritage Property.

Two broad concepts of conservation emerged in California during the debate over the controversial 1908-13 damming of the Hetch Hetchy Valley: the preservationist concept of John Muir, which was driven by a religious reverence for nature and the idea of the essential wild as an antidote to development, and a utilitarian concept of conservation proposed by Gifford Pinchot of wise use and 'banking' of nature for possible future use. The debate influenced the development of an international conservation movement: 'Dam Hetch

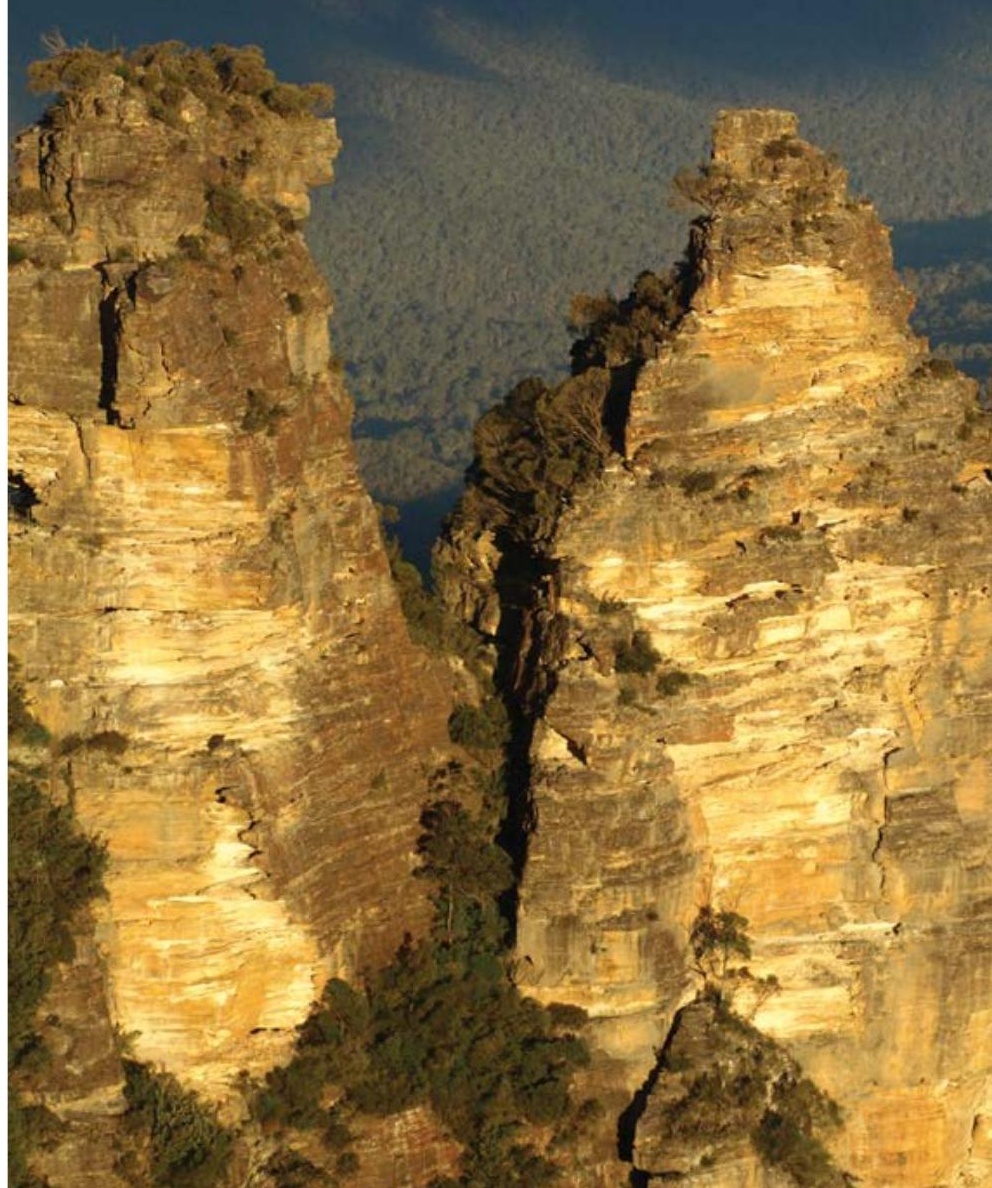

Greater Blue Mountains World Heritage Property, Australia

Source: Graeme L. Worboys

Hetchy! As well dam for water-tanks the people's cathedrals and churches, for no holier temple has ever been consecrated by the heart of man' (Muir 1912).

The protected area concept soon spread throughout the world in the 20th century, and new areas continue to be reserved in the 21 st century. Some important protected area-focused historical events since the end of World War II are provided in Table 2.1. 
Table 2.1 Some post-1945 protected area events

\begin{tabular}{|c|c|}
\hline Date & Event \\
\hline 1948 & $\begin{array}{l}\text { The International Union for Protection of Nature (IUPN) was formed as the first global organisation } \\
\text { for nature protection and was based in Brussels }\end{array}$ \\
\hline 1956 & The IUPN changed its name to the International Union for Conservation of Nature (IUCN) \\
\hline 1958 & IUCN's International Commission on National Parks was established \\
\hline 1962 & The first UN list of protected areas was prepared by the IUCN \\
\hline 1962 & The First World Conference on National Parks was held in Seattle, USA \\
\hline 1969 & An agreed definition of a national park was established by the IUCN General Assembly in New Delhi \\
\hline 1970 & UNESCO's Man and the Biosphere programme was launched \\
\hline 1971 & The Ramsar Convention on wetlands was adopted in Ramsar, Iran \\
\hline 1972 & The World Heritage Convention was adopted \\
\hline 1972 & The Second World Conference on National Parks was held at Yellowstone National Park, USA \\
\hline 1973 & $\begin{array}{l}\text { The Convention on International Trade in Endangered Species of Wild Fauna and Flora (CITES) } \\
\text { was adopted }\end{array}$ \\
\hline 1975 & $\begin{array}{l}\text { The IUCN International Commission on National Parks was changed to the IUCN Commission on } \\
\text { National Parks and Protected Areas (CNPPA) }\end{array}$ \\
\hline 1980 & $\begin{array}{l}\text { IUCN, the World Wide Fund for Nature (WWF) and the United Nation's Environment Programme (UNEP) } \\
\text { prepared the 'World Conservation Strategy' }\end{array}$ \\
\hline 1981 & $\begin{array}{l}\text { UNEP's World Conservation Monitoring Centre (UNEP-WCMC), based in Cambridge, undertook } \\
\text { responsibility for collecting and collating data on protected areas in partnership with the IUCN }\end{array}$ \\
\hline 1982 & The Third Word Congress on National Parks was held in Bali, Indonesia \\
\hline 1987 & $\begin{array}{l}\text { The report of the World Commission on Environment and Development (Our Common Future), dealing } \\
\text { with the sustainable development agenda, was published }\end{array}$ \\
\hline 1988 & IUCN adopted a definition for marine protected areas \\
\hline 1990 & The first report of the Intergovernmental Panel on Climate Change (IPCC) was produced \\
\hline 1991 & IUCN, WWF and UNEP prepared the document Caring for Earth: A strategy for sustainable living \\
\hline 1992 & $\begin{array}{l}\text { UNEP-WCMC in collaboration with IUCN CNPPA prepared a four-volume review of protected area } \\
\text { systems of the world }\end{array}$ \\
\hline 1992 & The Fourth World Congress on National Parks and Protected Areas was held in Caracas, Venezuela \\
\hline 1992 & $\begin{array}{l}\text { The Convention on Biological Diversity (CBD) was agreed to, recognising the need to conserve } \\
\text { biodiversity and the essential role of protected areas in doing this }\end{array}$ \\
\hline 1992 & The UN Framework Convention on Climate Change was achieved \\
\hline 1994 & IUCN published Guidelines for Protected Area Management Categories \\
\hline 1996 & The title of IUCN's CNPPA changed to the World Commission on Protected Areas (WCPA) \\
\hline 2000 & $\begin{array}{l}\text { The UN Millennium Development Goals were published and identified the need for } \\
\text { environmental sustainability }\end{array}$ \\
\hline 2000 & Conservation International identified its global environmental hotspots \\
\hline 2001 & WWF published its global ecoregions \\
\hline 2003 & IUCN's Fifth World Parks Congress was held in Durban, South Africa \\
\hline 2004 & $\begin{array}{l}\text { The Programme of Work on Protected Areas (PoWPA) was agreed to by the Convention on Biological } \\
\text { Diversity's Conference of Parties }\end{array}$ \\
\hline 2008 & $\begin{array}{l}\text { An improved definition of protected area and IUCN management categories and governance types } \\
\text { was approved at the Barcelona IUCN World Conservation Congress }\end{array}$ \\
\hline 2008 & The World Database on Protected Areas (WDPA) was upgraded and launched as an online database \\
\hline 2010 & $\begin{array}{l}\text { The CBD Strategic Plan for Biodiversity 2011-20 was launched and called for further protected areas to } \\
\text { be established, with improved connectivity, effective management and with due regard to people }\end{array}$ \\
\hline
\end{tabular}




\begin{tabular}{|l|l|}
\hline Date & Event \\
\hline 2010 & $\begin{array}{l}\text { IUCN WCPA prepared 'natural solutions' to emphasise the importance of protected areas as a } \\
\text { natural response to climate change }\end{array}$ \\
\hline 2011 & Guidelines for protected area legislation were prepared by IUCN's Environmental Law Centre and WCPA \\
\hline 2014 & $\begin{array}{l}\text { The Biodiversity and Protected Area Management (BIOPAMA) program was undertaken by the IUCN } \\
\text { to address threats to biodiversity in African, Caribbean and Pacific countries while reducing poverty } \\
\text { in communities in and around protected areas }\end{array}$ \\
\hline
\end{tabular}

Source: Adapted from Worboys (2014).

For readers interested further in the history of conservation, protected areas and the IUCN, an excellent text on these subjects is The Green Web by Martin Holdgate (1999).

The global concept of protected areas has benefited greatly from this evolving post-1945 thinking, discussion and refinement, and the importance of protected areas has increased, not diminished, during this time. Contemporary protected areas are lands and seas where people and communities of Earth have recognised the special natural, biodiversity, ecological, ecosystem service and/or social and cultural values and where they have taken steps to protect these values for the long term. The concept is intergenerational and recognises that the protection is supported by community and customary rules and/or the law of the land and that the area is actively managed. The concept may relate to very small or very large areas of Earth. They may be extremely fragile areas and managed sensitively; they may sustain communities; and they may host regular visits given their outstanding natural beauty.

\section{Purpose}

Protected areas are the principal mechanism for the conservation of biodiversity on Earth (as well as other natural and cultural heritage). This role for conserving biodiversity was formally recognised by 168 nation-states in 1992 in Article 8 of the newly created Convention on Biological Diversity (CBD). In the 21 st century, nearly all nations support the concept of protected areas. These areas underpin virtually all national and international conservation strategies where land, water or sea has been identified as vital and given special protection to maintain functioning natural ecosystems, to act as refuges for species and to maintain ecological processes that cannot otherwise survive in intensely managed areas such as agricultural or urban areas (Dudley 2008). Protected areas help to protect nature and this includes biodiversity at genetic, species and ecosystems levels as well as geodiversity including geoheritage, landforms, scenery, soils and water. Protected areas also protect cultural heritage given that the status and the management of

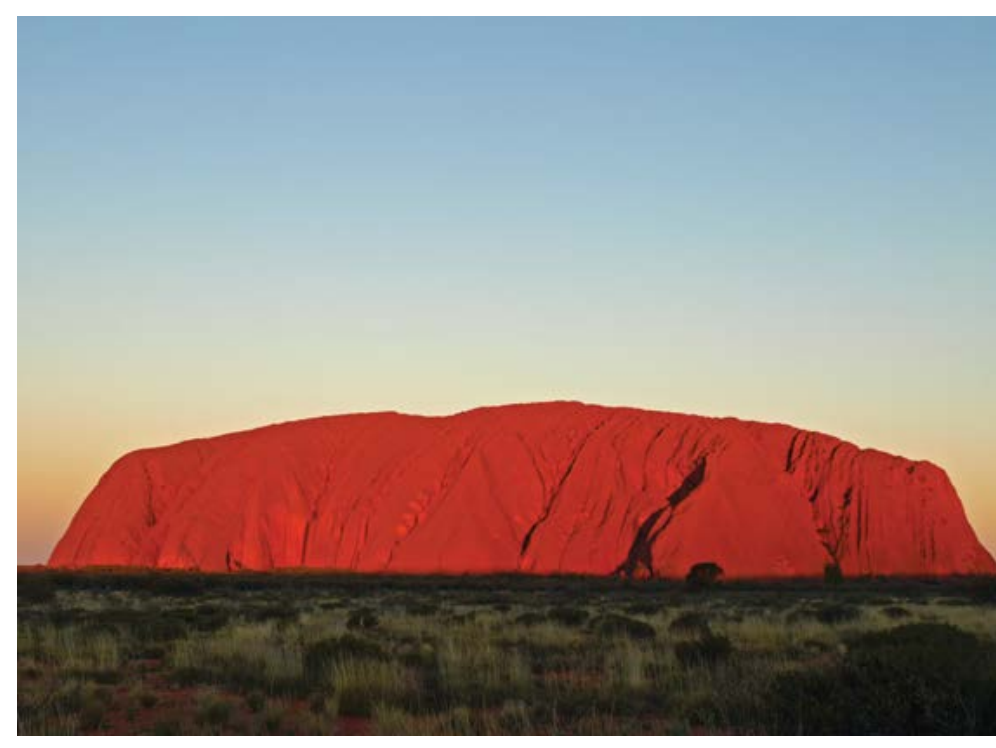

Uluru-Kata Tjuța National Park World Heritage Property, Australia

Source: Graeme L. Worboys

such cultural phenomena are not inconsistent with biodiversity conservation outcomes (Dudley 2008). For the sake of conciseness, henceforward in this book whenever we speak of 'biodiversity conservation' the additional values of ecosystem services, geodiversity and cultural heritage should be understood to be included. By articulating this greater purpose of protected areas it has helped to establish a protected area definition.

\section{Definition}

A protected area has been defined by the IUCN as '[a] clearly defined geographical space, recognised, dedicated and managed, through legal or other effective means, to achieve the long-term conservation of nature with associated ecosystem services and cultural values' (Dudley 2008:8).

Every word and phrase of this definition is important and has a clearly prescribed meaning. An explanation of this meaning has been prepared by Nigel Dudley of the IUCN and a summary of his description is provided here (Dudley 2008:8-9) (Table 2.2). 
Table 2.2 Details of the protected area definition

\begin{tabular}{|c|c|}
\hline Word or phrase & Explanation \\
\hline $\begin{array}{l}\text { Clearly defined } \\
\text { geographical space }\end{array}$ & $\begin{array}{l}\text { Geographical area: This includes land, inland water, marine and coastal areas or } \\
\text { a combination of two or more of these } \\
\text { Space: This has three dimensions and may include airspace and water column } \\
\text { space above land or above the bottom of the water body and subsurface areas } \\
\text { (such as caves) } \\
\text { Clearly defined: Implies a spatially defined area with agreed and demarcated } \\
\text { boundaries }\end{array}$ \\
\hline Recognised & $\begin{array}{l}\text { Protection can include a range of governance types declared by people as well } \\
\text { as those identified by a nation, but such sites should be recognised in some way } \\
\text { (such as listing on the World Database on Protected Areas) }\end{array}$ \\
\hline Dedicated & $\begin{array}{l}\text { Implies a specific binding commitment to conservation in the long term such as } \\
\text { international conventions and agreements; national, provincial and local laws; } \\
\text { customary law; covenants of NGOs; private trust and company policies; and } \\
\text { certification schemes }\end{array}$ \\
\hline Managed & $\begin{array}{l}\text { This assumes some active steps are being taken to conserve the natural } \\
\text { (and other) values for which the protected area was established. It may also } \\
\text { include a decision of non-intervention as the best conservation strategy }\end{array}$ \\
\hline $\begin{array}{l}\text { Legal or other effective } \\
\text { means }\end{array}$ & $\begin{array}{l}\text { Protected areas must be gazetted, recognised through an international } \\
\text { convention or agreement or else managed through other effective but non- } \\
\text { gazetted means such as through recognised traditional rules under which } \\
\text { community conserved areas operate or the policies of established NGOs }\end{array}$ \\
\hline ... to achieve & This implies some level of effectiveness of management \\
\hline Long term & $\begin{array}{l}\text { Protected areas should be managed in perpetuity and not as a short-term or } \\
\text { temporary management strategy }\end{array}$ \\
\hline Conservation & $\begin{array}{l}\text { This is the in situ maintenance of ecosystems and natural and semi-natural } \\
\text { habitats and of viable populations of species in their natural surroundings, and in } \\
\text { the case of domesticated or cultivated species, in the surroundings where they } \\
\text { have developed their distinctive properties }\end{array}$ \\
\hline Nature & $\begin{array}{l}\text { (In this context) always refers to biodiversity at genetic, species and ecosystem } \\
\text { levels and often also refers to geodiversity, landform and broader natural values }\end{array}$ \\
\hline $\begin{array}{l}\text { Associated ecosystem } \\
\text { services }\end{array}$ & $\begin{array}{l}\text { These are ecosystem services that are related to, but do not interfere with, the } \\
\text { aim of nature conservation - these can include provisioning (food and water) } \\
\text { services; regulating services (floods, drought, land degradation and disease); } \\
\text { support services (such as soil formation and nutrient cycling); and cultural } \\
\text { services such as recreational, spiritual, religious and other non-material benefits }\end{array}$ \\
\hline Cultural values & These include cultural values that do not interfere with the conservation outcome \\
\hline
\end{tabular}

\section{Types of protected areas: IUCN categories}

The IUCN has developed an internationally accepted category system for protected areas that identifies six categories of protected areas (Dudley 2008). A specific IUCN protected area category is assigned to a protected area consistent with its principal management objective. This IUCN framework serves as a common language for distinguishing, describing and working with broad protected area management types. This is critical given nations have otherwise assigned a wide range of descriptive terms that represent protected areas such as 'conservation park', 'conservation reserve', 'feature protection area', 'flora reserve', 'forest reserve', 'indigenous protection area', 'karst conservation reserve', 'national park', 'nature park', 'nature reserve', 'reference area', 'scientific area', and many others.

The six IUCN categories are differentiated by clear primary management objectives, and this common language helps to provide uniformity for data collection internationally and a capability for comparative analysis for the global protected area system. A definition and more specific differentiating guidelines help to define the 
- protected areas should usually aim to maintain or, ideally, increase the degree of naturalness of the ecosystem being protected

- the definition and categories of protected areas should not be used as excuses for dispossessing people of their land (Dudley 2008:10).

\section{Objectives}

Objectives of management that are common to all IUCN protected area categories include:

- conserve the composition, structure, function and evolutionary potential of biodiversity

- contribute to regional conservation strategies

- maintain diversity of landscape or habitat and of associated species and ecosystems

- be of sufficient size to ensure the integrity and longterm maintenance of the specified conservation targets

- maintain the values for which they were assigned in perpetuity

- be operating under the guidance of a management plan and a monitoring and evaluation program that support adaptive management

area near Ust Koksa, Altai Republic, Russia

Source: Graeme L. Worboys

six IUCN protected area categories and each has been described here along with this guiding information. First, however, there is a set of fundamental management principles and objectives that are common to all IUCN categories.

\section{Principles}

Principles for IUCN protected area categories help to clarify exactly what the IUCN means by protected areas and help to maintain the integrity of its categories. Consistent with the IUCN definition of a protected area, key principles for the IUCN categories are:

- only those areas where the main objective is conserving nature can be considered protected areas

- protected areas must prevent, or eliminate where necessary, any exploitation or management practice that will be harmful to the objectives of designation

- the choice of category should be based on the primary objective(s) stated for each protected area

- the category system is not intended to be hierarchical

- any category can exist under any governance type and vice versa

- possess a clear and equitable governance system (Dudley 2008:12).

\section{IUCN protected area categories}

The six IUCN categories are individually introduced, defined and their primary objective presented. These descriptions are a critical guide for the effective management of protected areas and should always be aspirational whatever the situational circumstances of individual protected areas.

\section{Category la: Strict Nature Reserve}

Category Ia Strict Nature Reserves conserve ecosystems, species and geodiversity and may be important sites for scientific research, environmental monitoring and education. They may also be important sites for conserving cultural and spiritual values associated with nature. Strict nature reserves are extremely important in the 21 st century, for there are fewer and fewer areas where the activities of humans are limited. They help to protect scarce natural heritage that would otherwise be lost without this designation, and they may provide a baseline for long-term environmental monitoring as well as protecting other scarce natural resources and ecosystem services. 


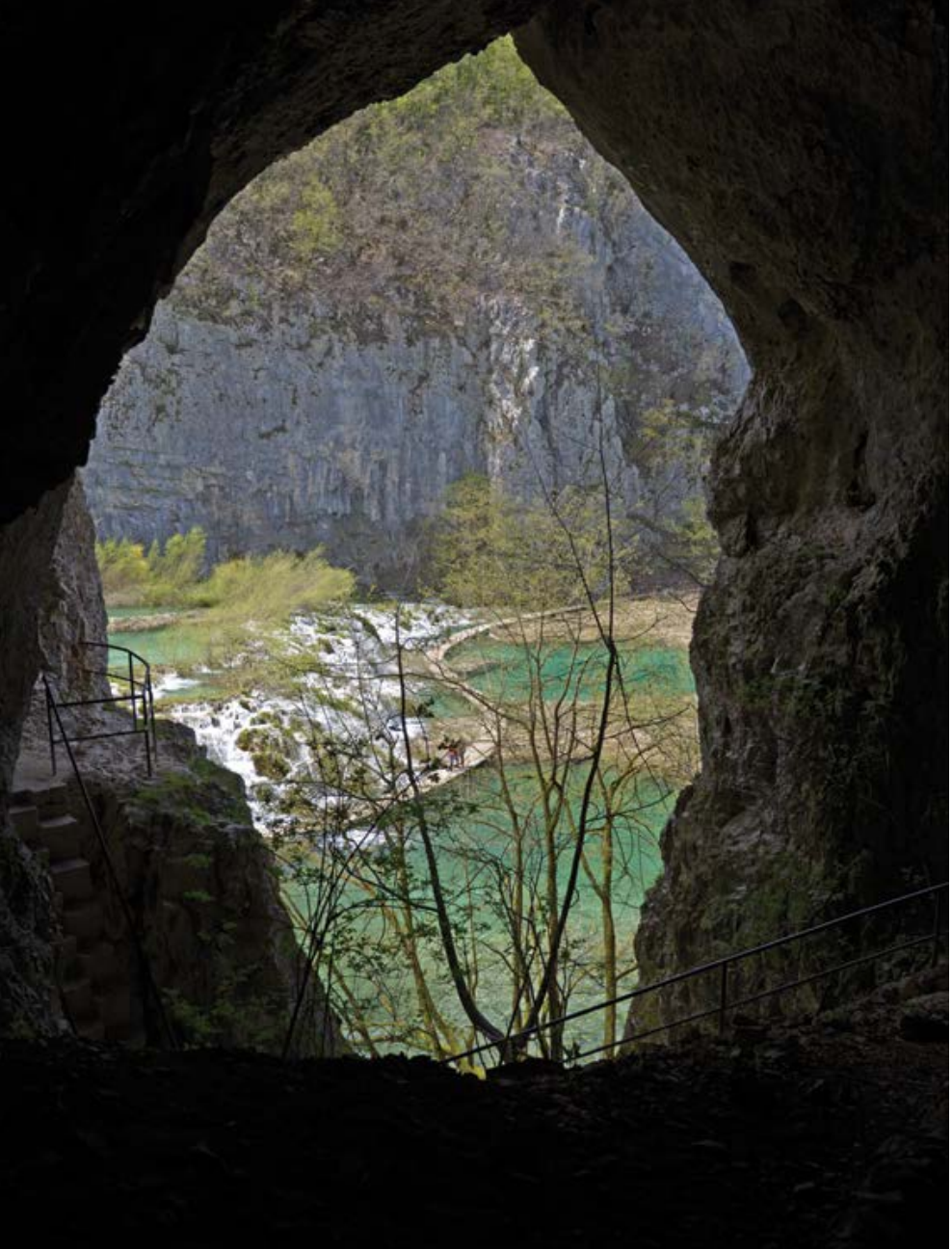

Plitvice Lakes National Park, World Heritage Property, Croatia

Source: Graeme L. Worboys

\section{Definition}

Category Ia are strictly protected areas set aside to protect biodiversity and also possibly geological/ geomorphological features, where human visitation, use and impacts are strictly controlled and limited to ensure protection of the conservation values. Such protected areas can serve as indispensable reference areas for scientific research and monitoring (Dudley 2008:13).

\section{Primary objective}

The primary objective of a Category Ia protected area is to conserve regionally, nationally or globally outstanding ecosystems, species (occurrences or aggregations) and/ or geodiversity features. These attributes will have been formed mostly or entirely by non-human forces and will be degraded or destroyed when subjected to all but very light human impact (Dudley 2008:13).

\section{Category lb: Wilderness Area}

Category Ib Wilderness Areas help protect relatively untouched and functioning ecosystems, and consequently, provide opportunities for evolution to continue in as natural a state as possible and where species can survive. They provide opportunities for limited numbers of visitors to experience wilderness and may also include livestock grazing by nomadic peoples.

\section{Definition}

Category Ib protected areas are usually large unmodified or slightly modified areas, retaining their natural character and influences, without permanent or significant human habitation, which are protected and managed so as to preserve their natural condition (Dudley 2008:14).

\section{Primary objective}

The primary objective of a Category Ib protected area is to protect the long-term ecological integrity of natural areas that are undisturbed by significant human activity, free of modern infrastructure and where natural forces and processes predominate, so that current and future generations have the opportunity to experience such areas (Dudley 2008:14).

\section{Category II: National Park}

Category II National Parks are large areas where natural ecological processes, including evolutionary processes with less human interference, may continue. They help conserve superlative natural scenery, diverse landscapes, rich geoheritage, biodiversity including key species, ecosystem services and rich cultural heritage, and they may form a core area for larger connectivity conservation initiatives. They may be internationally famous for their scenic grandeur, their remarkable natural phenomena and exceptional wildlife species and often include a range of visitor services and support facilities.

\section{Definition}

Category II protected areas are large natural or near natural areas set aside to protect large-scale ecological processes, along with the complement of species and ecosystems characteristic of the area, which also provide a foundation for environmentally and culturally compatible spiritual, scientific, educational, recreational and visitor opportunities (Dudley 2008:16).

\section{Primary objective}

The primary objective of a Category II protected area is to protect natural biodiversity along with its underlying ecological structure and supporting environmental processes, and to promote education and recreation (Dudley 2008:16). 


\section{Category III: Natural Monument or Feature}

Category III protected areas are typically small and are focused on a natural feature or features and their associated ecosystems. They could include features such as cliffs, waterfalls, caves or forest groves, and may also be of importance as cultural sites including sacred natural sites. Visitor use of the site may be encouraged.

\section{Definition}

Category III protected areas are set aside to protect a specific natural monument, which can be a landform, seamount, submarine cavern, geological feature such as a cave or even a living feature such as an ancient grove. They are generally quite small protected areas and often have high visitor value (Dudley 2008:17).

\section{Primary objective}

The primary objective of a Category III protected area is to protect specific outstanding natural features and their associated biodiversity and habitats (Dudley 2008:17).

\section{Category IV: Habitat/Species Management Area}

Category IV protected areas help to protect fauna and flora species that are usually of international, national or local importance and they help to protect key habitats. They may be small, but the size of these areas varies. They may include only fragments of an ecosystem, which may require regular and active management to sustain and perhaps more than implemented for Category I and II protected areas.

\section{Definition}

Category IV protected areas aim to protect particular species or habitats and management reflects this priority. (Many Category IV protected areas will need regular, active interventions to address the requirements of particular species or to maintain habitats, but this is not a requirement of the category [Dudley 2008:19].)

\section{Primary objective}

The primary objectives of a Category IV protected area are to maintain, conserve and restore species and habitats (Dudley 2008:19).

\section{Category V: Protected Landscape/ Seascape}

Category V protected areas are landscapes/seascapes of distinctive scenic quality and include important flora and fauna habitats and cultural features. They ideally feature a balanced interaction between humans and nature and provide opportunities for the restoration of nature and the maintenance of place-dependent cultural activities. They play an important role at a landscape or seascape scale and may contribute to conservation as part of a mosaic of conservation land or sea use that could include other protected area categories and connectivity conservation areas.

\section{Definition}

The Category V protected landscape/seascape is a protected area where the interaction of people and nature over time has produced an area of distinct character with significant ecological, biological, cultural and scenic values, and where safeguarding the integrity of this interaction is vital to protecting and sustaining the area and its associated nature conservation and other values (Dudley 2008:20).

\section{Primary objective}

The primary objectives of a Category V protected area are to protect and sustain important landscapes/seascapes and the associated nature conservation and other values created by interactions with humans through traditional management practices (Dudley 2008:20).

\section{Category VI: Protected Area with Sustainable Use of Natural Resources}

Category VI protected areas may be large areas and may be part of conservation initiatives such as large connectivity conservation areas. They are areas where the sustainable use of natural resources is a means to help achieve nature conservation together with protection objectives. This category does not accommodate largescale industrial harvesting and it is recommended by the IUCN that a proportion (such as 66 per cent) of the area is retained in a natural condition.

\section{Definition}

Category VI protected areas conserve ecosystems and habitats, together with associated cultural values and traditional natural resource management systems. They are generally large, with most of the area in a natural condition, where a proportion is under sustainable natural resource management and where low-level non-industrial use of natural resources compatible with nature conservation is seen as one of the main aims of the area (Dudley 2008:22). 


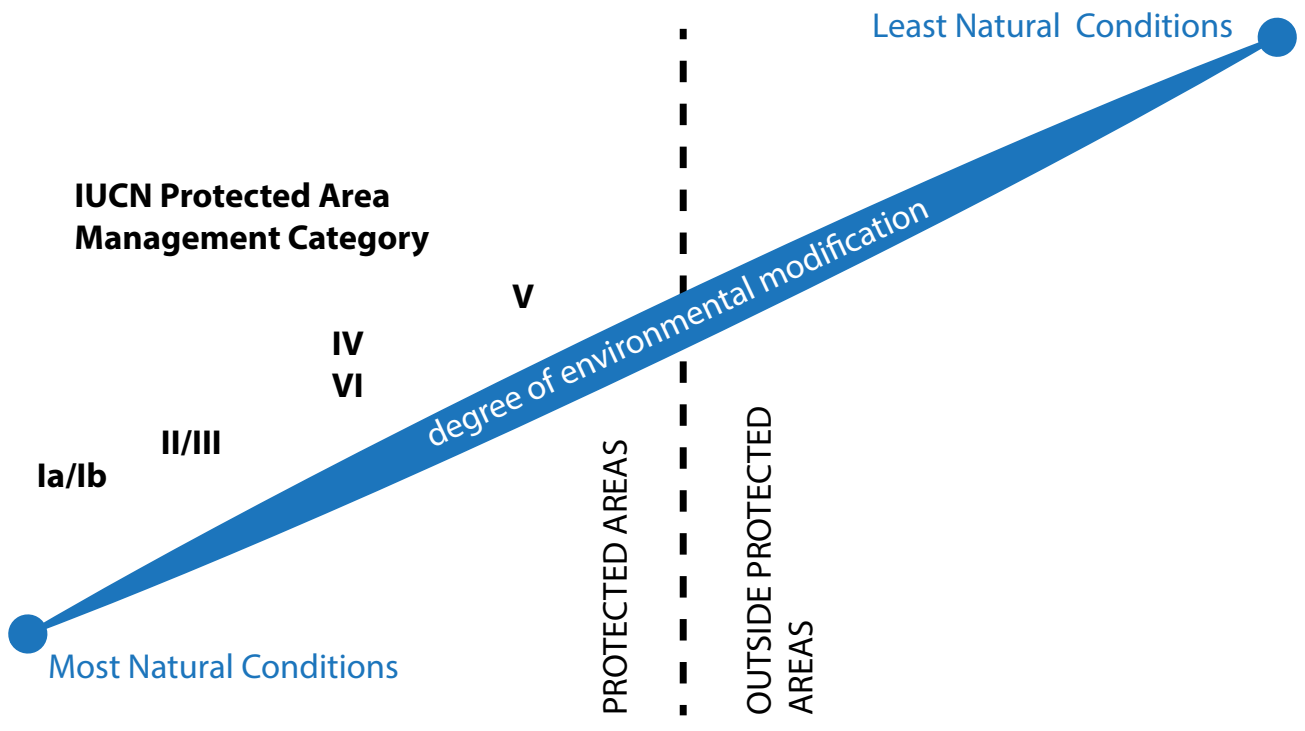

Figure 2.1 Naturalness and IUCN protected area categories

Source: Adapted from Dudley (2008:24)

\section{Primary objective}

The primary objectives of a Category VI protected area are to protect natural ecosystems and use natural resources sustainably when conservation and sustainable use can be mutually beneficial (Dudley 2008:22).

\section{The six categories}

The six categories are not designed as a hierarchical suite of categories in terms of quality, importance or naturalness; rather, their application is situational and is based on maximising nature conservation for a particular landscape/seascape context (Dudley 2008:24). The application of the IUCN categories in the context of 'naturalness' is illustrated in Figure 2.1.

\section{Systems of protected areas}

Systems of protected areas are where a number of protected areas have been established by a nation, sub-national governments, NGOs or other private organisations. In national protected area systems, the diversity of landforms, ecosystems, fauna and flora as found in each nation is ideally conserved through a conservation sampling within a number of carefully selected protected areas. Such a national system of protected areas aims to maximise the in situ conservation of a nation's natural heritage and ideally has five key elements that underpin the system (Davey 1998; Dudley 2008). Protected areas as a system need to also demonstrate the principles of good governance (Chapter 7), and a protected area system may include a diversity of governance types such as government managed, co-managed, indigenous peoples' and community conserved territories and areas, and private protected areas. The five key elements that characterise a protected area system are as follows (Davey 1998).

1. Representative, comprehensive and balanced: There are high-quality examples of the full range of environment types within a country and the protected areas in the system provide a balanced sample.

2. Adequate: Each protected area has integrity (it is in good condition) and there is sufficiency of spatial extent and arrangement of contributing units to ensure the viability of species and ecological processes.

3. Coherent and complementary: There is a positive contribution of each protected area in the system towards the conservation and sustainable development objectives of a nation.

4. Consistent: There is consistency in approach to achieving management objectives for the entire system.

5. Cost effective, efficient and equitable: There is balance between costs and benefits and equity in the distribution of financial resources within the system and there is efficiency with the system (the minimum number and size of protected areas have been established to achieve system objectives). 


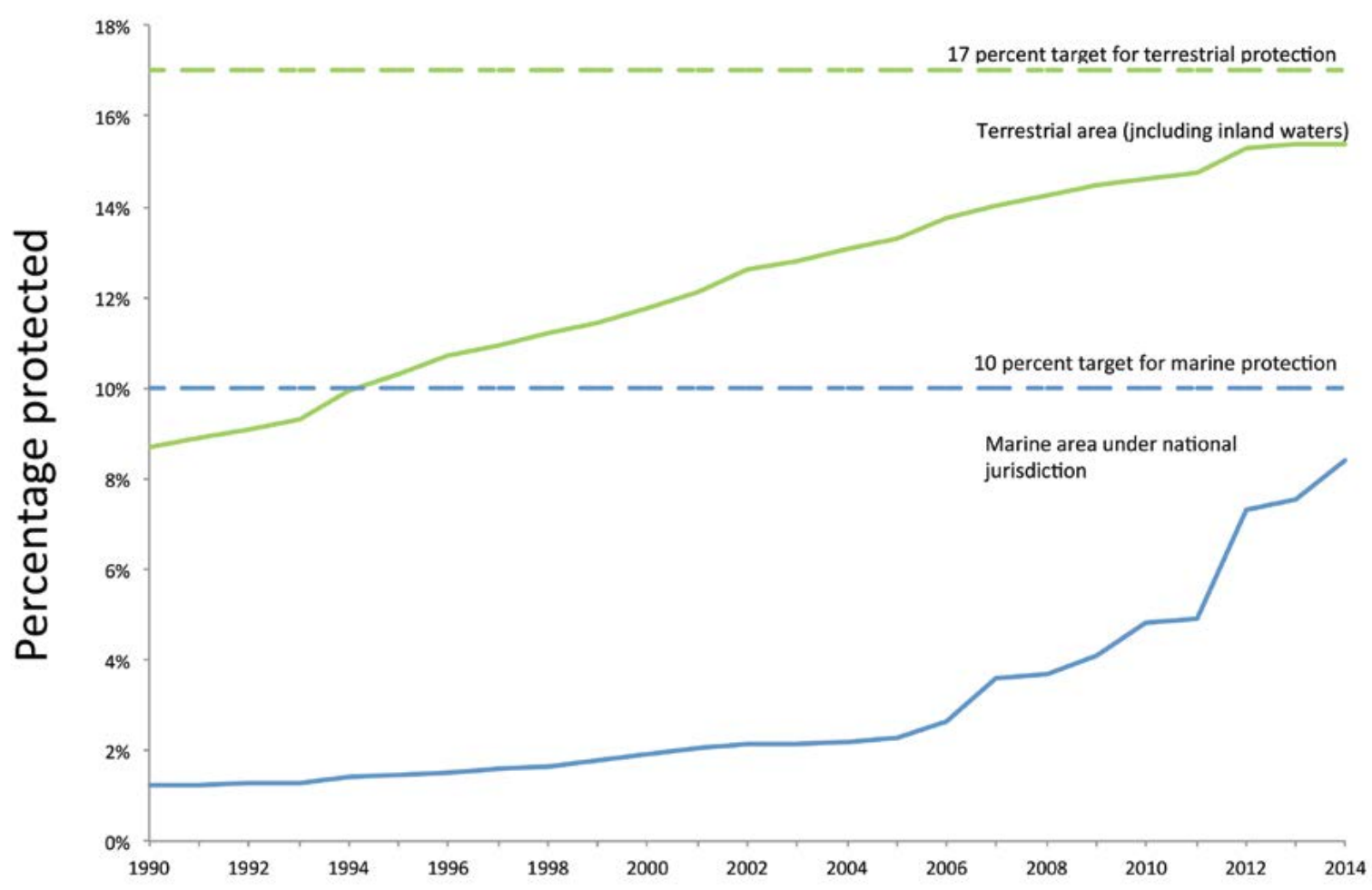

Figure 2.2 Growth in the percentage of terrestrial and marine area covered by protected areas, 1990-2014. The years are extracted from the protected area status year reported to the World Database on Protected Areas (WDPA). Protected areas with no reported status year were included in the 1990 baseline. Global statistics from the WDPA, August 2014

Source: UNEP-WCMC Cambridge

\section{Status of protected area coverage}

In 1962, at the first World Conference on National Parks in Seattle, Washington, there were just 9214 protected areas identified for the world (Chape et al. 2003), and just 52 years later, in 2014, there were over 209,000 designated protected areas (IUCN and UNEP-WCMC 2014). This 20th and 21st-century transformation has meant that by 2014 , some 15.4 per cent of the world's terrestrial and inland waters were protected, as were 3.4 per cent of the total marine area, including 8.4 per cent of marine areas under national jurisdiction and 8.0 per cent of national exclusive economic zones (IUCN and UNEPWCMC 2014). It has been a remarkable achievement. It is one of the greatest peaceful land-use and sea-use transformations in human history (Figure 2.2), though this work is unfinished.

The data and protected area statistics described have been compiled in the World Data Base on Protected Areas (WDPA) that is managed by UNEP's World Conservation Monitoring Centre in Cambridge and includes protected areas of all IUCN governance types. In addition to government protected areas it includes hundreds of community-managed, co-managed and private protected areas (including vast areas in Brazil and Australia). However, it is not complete, as the majority of such non-government protected areas are not formally recognised or reported by governments for various reasons. An indicative appraisal of the larger (nonrecorded) extent of Indigenous Peoples' and Community Conserved Territories and Areas (ICCAs) has been completed (Kothari et al. 2012). The number of ICCAs may have equalled or exceeded the number and extent of WDPA recognised protected areas.

Protected areas are recognised as an effective tool for conserving biodiversity and specifically many endangered species at a time of global change (Butchart et al. 2012). This is at a time when the sixth great extinction event on Earth is forecast, caused primarily by human activity (UNEP 2007). The aspirational target for 2020 reservation for nations established by the Convention on Biological Diversity's strategic plan 2011-20 (CBD 2011) is 17 per cent for their terrestrial area and 10 per cent for marine areas. The target calls on the areas to be important for biodiversity conservation such as key biodiversity areas (see Chapter 3). All IUCN protected area categories are important for biodiversity conservation, although some key biodiversity areas may need special protection to ensure species remain extant. Such management may 


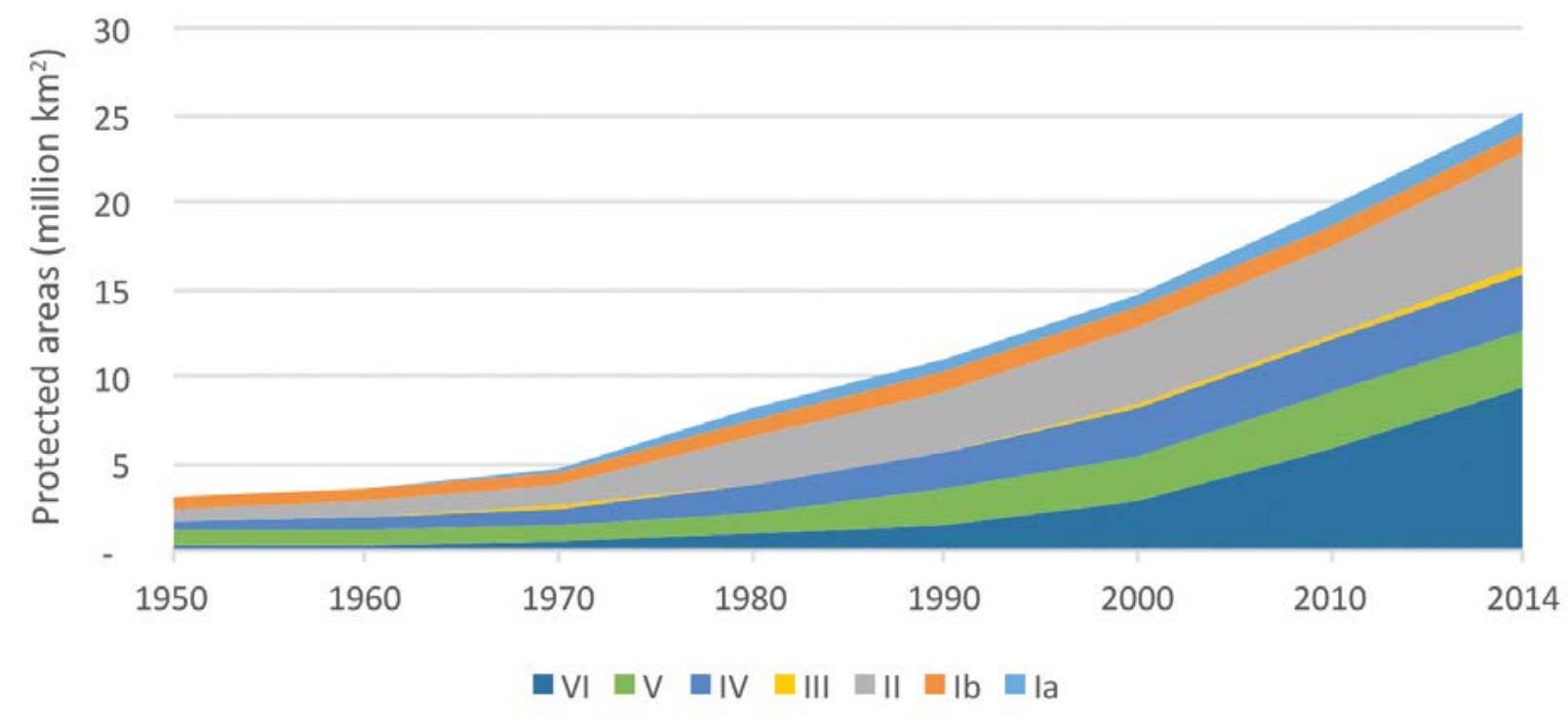

Figure 2.3 Total areal extent $\left(\mathrm{km}^{2}\right)$ of protected areas in the WDPA in each of the IUCN management categories, 1950-2014. The overall protected area in all categories is inflated due to overlaps of protected areas within and across categories. The graph includes undated protected areas with category information in all years and excludes protected areas with no category information.

Source: WDPA August 2014

be best established under the objectives and management guidance for Category I-IV protected areas (Figure 2.3), although Categories V and VI also play a valuable role in contributing to such biodiversity conservation.

\section{Other international protected area and conservation types}

\section{World Heritage properties}

In 1972, adoption of the World Heritage Convention (UNESCO 2013a) by the United Nations established the World Heritage List and provided an opportunity to recognise the most exceptional natural and cultural heritage places of Earth. This is a prestigious list, and in 2012 there were 190 parties who had ratified the convention (UNESCO 2013b), meaning it was almost universally adopted.

The convention recognises that World Heritagelisted natural and cultural heritage are irreplaceable assets of outstanding universal value not only for each nation but also for humanity as a whole (UNESCO 2011). The convention aims for the identification, protection, conservation, presentation and transmission to future generations of cultural and natural heritage of 'outstanding universal value' (OUV) (UNESCO 2011). For 'cultural heritage', the convention recognises monuments, groups of buildings and sites that feature the works of people or the combined works of nature and people (UNESCO 2011). The World Heritage 'natural heritage' criteria include natural aesthetic landscape features, geological and physiographic formations, significant ecosystems and ecosystem processes, species and precisely defined natural areas of OUV (UNESCO 2011). The convention also recognises 'mixed cultural and natural heritage properties' and 'cultural landscapes'.

There is a rigorous process for achieving inscription on the World Heritage List that includes assessments against the OUV criteria, an evaluation of integrity/ and or authenticity and a review of the protection and management of the property. If World Heritage status is achieved, as part of the convention, there is a requirement for each state party to maintain the World Heritage OUV and to provide periodic reports on the condition and trend in condition of the OUV. World Heritage properties may be designated over any land tenure, however, there is a requirement that the OUV is conserved. Usually World Heritage properties are inscribed over lands coincident with established protected areas, especially given the need for an effective management regime. World Heritage sites around the world are therefore special and ideally represent the 'best of the best' of Earth's natural and cultural heritage. Chapter 3 provides further information about natural World Heritage properties recognised by the World Heritage Convention. 


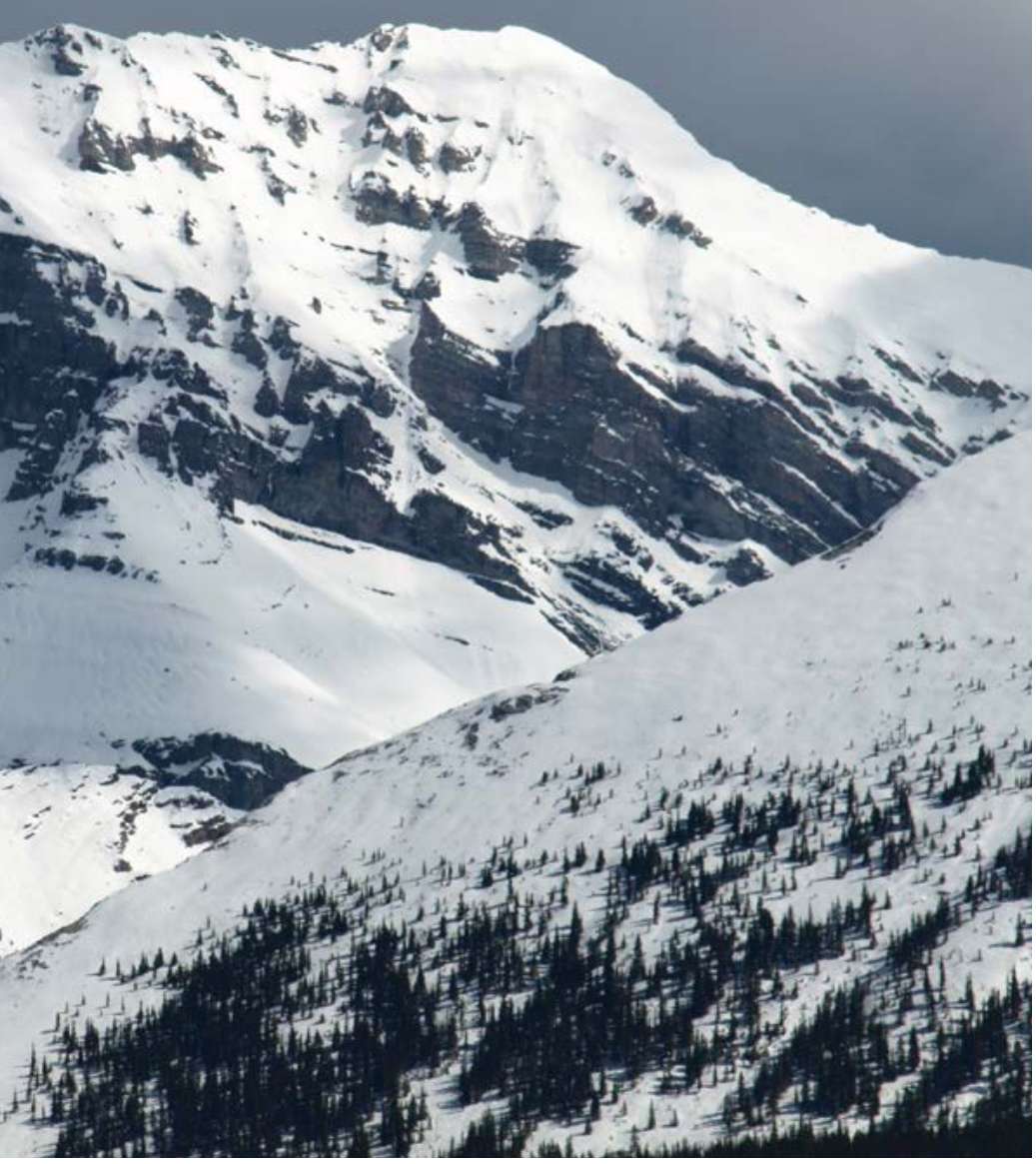

Banff National Park World Heritage Property, Canada

Source: Graeme L. Worboys

\section{Ramsar Wetlands}

Wetlands of importance may be officially recognised under the provisions of the Ramsar Convention. This treaty was adopted in 1971 in the city of Ramsar, Iran, and in 2013 there were 168 contracting parties to the convention and 2168 recognised sites around the world (Ramsar 2013). The convention uses a broad definition of the types of wetlands covered by its mission including lakes and rivers; swamps and marshes; wet grasslands and peatlands; oases; estuaries; deltas and tidal flats; near-shore marine areas; mangroves and coral reefs; and human-made sites such as fish ponds, rice paddies, reservoirs and salt pans. The convention's mission is 'the conservation and wise use of all wetlands through local and national actions and international cooperation, as a contribution towards achieving sustainable development throughout the world' (Ramsar 2013:1). The parties commit to undertaking an inventory of their wetlands and preparing a strategic framework for the Ramsar list. This includes establishing systematic and representative national designation and management of wetland habitat types. There is no obligation for Ramsar sites to be legally protected, though listing status does enhance protection (Dudley 2008). Chapter 19 of this book deals further with areas recognised by the Ramsar Convention.

\section{UNESCO Man and the Biosphere Programme (biosphere reserves)}

Biosphere reserves are part of the Man and the Biosphere (MAB) Programme. It was launched by the UN Educational, Scientific and Cultural Organisation (UNESCO) in 1971 as an intergovernmental scientific program that aims to set a scientific basis for the improvement of the relationships between people and their environment globally (UNESCO 2013c). In 2013, the World Network of Biosphere Reserves included 621 reserves in 117 countries (UNESCO 2013c). The MAB Programme combines natural and social sciences, economics and education to improve human livelihoods and safeguard natural ecosystems, and thus aims to promote innovative approaches to economic development that are socially and culturally appropriate and environmentally sustainable.

Biosphere reserves aim to achieve the integrated management of land, fresh water, marine waters and living resources by establishing bioregional planning schemes (and zones) to achieve sustainable development. Implementation of the zones is left to the discretion of nations, and they include core zones (ideally protected areas) that are surrounded by buffer zones (where conservation is emphasised) and a transition zone (or area of cooperation that promotes sustainable development) (UNESCO 2002). Biosphere reserves are described on their nomination form by UNESCO (2013b:1):

Biosphere reserves are areas of terrestrial and coastal/marine ecosystems, or a combination thereof, which are internationally recognized within the framework of UNESCO's Programme on Man and the Biosphere (MAB). They are established to promote and demonstrate a balanced relationship between humans and the biosphere. Biosphere reserves are designated by the International Coordinating Council of the MAB Programme at the request of the State concerned. Individual biosphere reserves remain under the sovereign jurisdiction of the State where they are situated. Collectively, all biosphere reserves form a World Network in which participation by States is voluntary. 
The World Network of Biosphere Reserves is governed by a framework adopted by the UNESCO General Conference in 1995, which presents the definition, objectives, criteria and designation procedure for biosphere reserves. The actions recommended for the implementation of biosphere reserves are set out in a document referred to as the 'Seville Strategy', and this was further developed as the 'Madrid Action Plan' (2008-13) (UNESCO 2013d). Requirements for areas to be recognised as a biosphere reserve are given in Box 2.1.

\section{UNESCO Geoparks}

The concept of geoparks evolved as a basis for protecting areas of special geological features. UNESCO adopted the concept in 2001, and provided the following guidance:
A Global Geopark is a unified area with geological heritage of international significance. Geoparks use that heritage to promote awareness of key issues facing society in the context of the dynamic planet we all live on. Many Geoparks promote awareness of geological hazards, including volcanoes, earthquakes and tsunamis and many help prepare disaster mitigation strategies among local communities. Geoparks hold records of past climate change and are educators on current climate change as well as adopting a best practice approach to utilising renewable energy and employing the best standards of green tourism. (UNESCO 2014:1)

Geoparks provide information about the sustainable use of and need for natural resources, whether they are mined, quarried or harnessed from the surrounding environment, while at the same time promoting respect for the environment and the integrity of the landscape. Geoparks are not a legislative designation, though the key geoheritage sites within a geopark should be protected under the appropriate legislation (UNESCO 2013e). The Global Network of National Geoparks is a voluntary network supported by UNESCO whose members are committed to work together and exchange ideas of best practice and join in common projects (UNESCO 2013e). Chapter 18 of this book deals further with UNESCO geoparks.

\section{Introducing non-government protected areas}

'Conventional' protected areas are commonly thought of as protected areas established and managed by national governments, especially given the commitment of these governments to the Convention on Biological Diversity and to the implementation of the CBD strategic plan 2011-20. Sub-national governments also establish protected areas. In addition to these government protected areas, around the world in the 21 st century, there has been greater recognition of the traditional and continuing role of indigenous peoples and local communities, and of individuals, civil society organisations and the private sector in the conservation of land, including the governance and management of protected areas.

Innovation in conservation, protection and management has been called for (Figgis 2012) at a time when a cocktail of threats such as increased human pressures including habitat destruction and poaching, pollution and climate change, severe weather events and fires, and introduced species are impacting the Earth's biodiversity. Two types of non-government protected areas are recognised widely, including by the IUCN and by governments as part of the CBD Programme of Work on Protected Areas: Indigenous Peoples' and Community Conserved Territories and Areas (ICCAs) and Private Protected Areas (PPAs). A third type, Shared Governance or Collaboratively Managed Protected Areas, contains sites managed by two or more of these agencies and groups. Together with government-protected areas, these constitute the four governance types now globally recognised (see Chapter 7).

\section{Indigenous Peoples and Community Conserved Territories and Areas}

Outside formal tribal governments such as those in the United States, indigenous peoples and local and mobile communities may establish, govern and manage ICCAs (Borrini-Feyerabend et al. 2004). ICCAs provide an important contribution to biodiversity conservation in many parts of the world. They have been defined as 'natural and modified ecosystems with significant biodiversity, ecological and related cultural values, voluntarily conserved by indigenous peoples and local communities through customary laws or other effective means' (Kothari et al. 2012:16). 


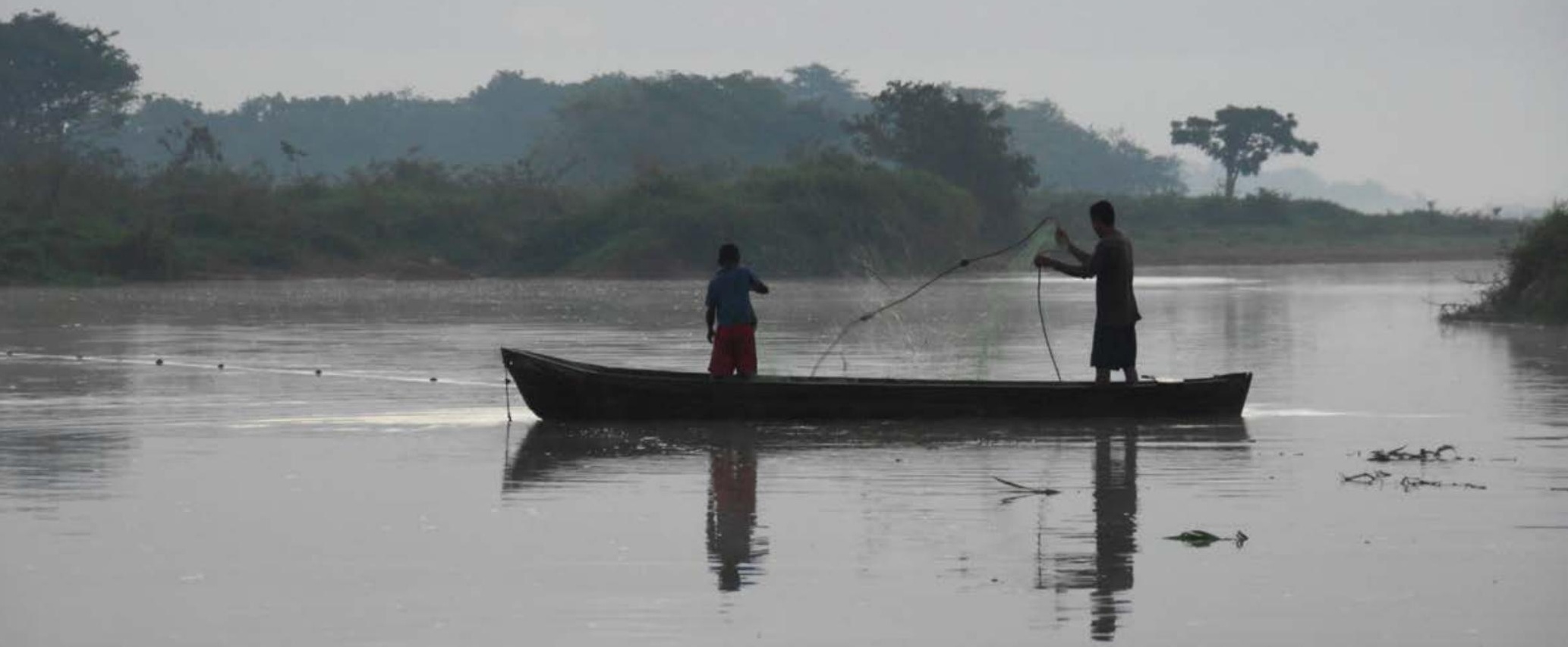

Rio Platano Biosphere Reserve, Honduras

Source: Eduard Müller

\section{Box 2.1 UNESCO criteria for designation as biosphere reserve}

Article 4 of the biosphere reserve framework presents seven general criteria for an area to be qualified for designation as a biosphere reserve. It would:

1. Encompass a mosaic of ecological systems representative of major biogeographic region(s), including a gradation of human interventions.

2. Be of significance for biological diversity conservation.

3. Provide an opportunity to explore and demonstrate approaches to sustainable development on a regional scale.

4. Have an appropriate size to serve the three functions of biosphere reserves.

5. Through appropriate zonation, achieve

a. a legally constituted core area or areas devoted to long-term protection, according to the conservation objectives of the biosphere reserve, and of sufficient size to meet these objectives

b. a buffer zone or zones clearly identified and surrounding or contiguous with the core area or areas, where only activities compatible with the conservation objectives can take place c. an outer transition area where sustainable resource management practices are promoted and developed.

6. Have organisational arrangements that provide for the involvement and participation of a suitable range of inter alia public authorities, local communities and private interests in the design and carrying out of the functions of a biosphere reserve.

7. Have mechanisms for implementation that include

a. mechanisms to manage human use and activities in the buffer zone or zones

b. a management policy or plan for the area as a biosphere reserve

c. a designated authority or mechanism to implement this policy or plan

d. programs for research, monitoring, education and training?

Source: UNESCO (2013b) 
This encompasses three essential features (Kothari et al. 2012:17).

1. A well-defined people or community with a close and profound relation with an equally well-defined site (a territory, area or species habitat, though the boundaries may be flexible) and/or species; this is a relation rooted in culture, sense of identity and/or dependence for livelihood or wellbeing.

2. The people or community as the major player in decision-making and implementation regarding the governance and management of the site and/or species, implying local institutions have the de facto and/or the de jure (formal equality) capacity to develop and enforce decisions. Other rights-holders and stakeholders may collaborate as partnersespecially when the land is owned by the statebut local decisions and management efforts are predominant.

3. The people's or community's management decisions and efforts lead to the conservation of habitats, species, genetic diversity, ecological functions/ benefits and associated cultural values, even when the conscious objectives of management are not conservation alone.

There are many different types of ICCAs (Box 2.2). Not all of these ICCAs are protected areas, but all of them help to conserve biodiversity and include many values and benefits (Box 2.3). ICCAs may be very small or extend over several million hectares, and are found in many countries of the world. Neema Pathak (Case Study 2.1) has researched details of their characteristics in India. Chapter 7 provides further information on ICCAs.

\section{Australian Indigenous Protected Areas}

The Australian Government has supported the development of Indigenous Protected Areas (IPAs) since 1997 and has defined these as 'an area of Indigenousowned land or sea where traditional owners have entered into an agreement with the Australian Government to promote biodiversity and cultural resource conservation' (Government of Australia 2013:1).

IPAs do not have an overarching legal framework; rather they rely on Indigenous communities identifying their wish to dedicate their land for conservation purposes. IPAs are formally recognised as a protected area under Australia's National Reserve System through the 'legal and other effective means' clause of the IUCN protected area definition (Rose 2013). In 2013, there were 60 declared IPAs covering just more than 48 million hectares across Australia, contributing more than one-third of the National Reserve System (Government of Australia
2013). IPAs deliver more than environmental benefits; importantly, they provide communities with significant health, education, economic and social benefits as well as protecting their significant cultural values.

\section{Private protected areas}

Privately owned and managed protected areas have been in existence for centuries (such as the private hunting reserves of Mongolia and Europe) (Langholz 2005). Privately protected areas are now being encouraged by some nations as a mechanism for biodiversity conservation that complements community-based and government reserves. The IUCN defined a private protected area at the 2003 IUCN World Parks Congress as 'a land parcel of any size that is 1) predominantly managed for biodiversity conservation; 2) protected with or without formal government recognition; and 3) is owned or otherwise secured by individuals, communities, corporations or non-governmental organisations' (Chape et al. 2008:102).

Private protected areas have been established, for example, in Chile (Pumalin Park), southern and eastern Africa (such as the game reserves that adjoin Kruger National Park), Namibia (Namib Rand Nature Reserve), the United States (the Gray Ranch) and the United Kingdom (the Royal Society for the Protection of Birds with its 150 reserves totalling more than 240 000 hectares) (Langholz 2005). In Australia several NGOs have purchased substantial properties and manage them for biodiversity outcomes, including Bush Heritage Australia, the Australian Wildlife Conservancy and Tasmanian Land Conservancy. Also notable are The Nature Conservancy preserves and easement lands in the United States, which currently protect approximately 6.1 million hectares (TNC 2013).

\section{Other conservation initiatives that complement protected areas}

There are many initiatives and effective area-based conservation measures that do not meet the definition of a protected area or where protected area status is not sought, but still contribute to biodiversity conservation outcomes. These include voluntary wildlife sanctuaries, roadside greenways, conserved riparian areas in production forests, conservation areas in government-owned forests, wetlands and forested areas retained on farmland, along streams, tourist areas, private ecotourism destinations, ICCAs outside the protected area system, military areas and even university campuses. Regenerating former agricultural areas, urban parks, public gardens and private estates and gardens (especially with native species) can all contribute to conservation of native biodiversity in the landscape. 


\section{Case Study 2.1 Community Conserved Areas in India}

Neema Pathak, in her contribution to our knowledge of community conserved areas (CCAs) in India, acknowledged the enormous challenge of defining CCAs for her country. She established a working definition, which identified CCAs as '[n]atural ecosystems (forest/ marine/wetlands/grasslands/others), including those with minimum to substantial human influence, containing significant wildlife and biodiversity value, being conserved by communities for cultural, religious, livelihood, or political purposes, using customary law or other effective means' (Pathak 2009:49).

She also identified six criteria for recognising CCAs for India.

1. There is an identified group of people who can be considered a community who are involved in the effort.

2. The concerned communities have substantial ethical livelihood, cultural, economic or spiritual associations with and dependence on the conserved area.
3. The concerned communities are the major players or among the major players in decision-making and implementation of decisions.

4. The concerned communities have established systems (institutions, regulations, processes) for achieving their objectives.

5. Irrespective of the objective of the initiative, the efforts lead to maintenance or enhancement of one or more natural ecosystems and species therein.

6. The effort is taking place within a locally identified boundary (Pathak 2009:50-1).

Source: Pathak (2009)

\section{Box 2.2 Types of ICCAs}

There are several kinds of ICCAs and they are listed here. Not all of these ICCAs are protected areas, but they do help to conserve biodiversity (see Chapter 7 ).

- Indigenous peoples' territories governed and managed as part of their history and life, encompassing sustainable use, cultural values and/or, in more recent times, explicit conservation objectives. For example, indigenous territories with multiple villages in Suriname, Indigenous Protected Areas in Australia, indigenous reserves in Costa Rica and indigenous 'Comarcas' in Panama.

- Territories (terrestrial or marine) over which mobile or nomadic communities have traditionally roamed, managing the resources through customary regulations and practices-for example, customary rangelands of tribal confederacies in Iran, and pastoral landscapes in Kenya and Ethiopia.

- Sacred natural sites or spaces, ranging from tiny groves and wetlands to entire landscapes and seascapes, often (but not necessarily) left completely or largely inviolate. For example, sacred groves and landscapes of South Asia, sacred lakes and marine burial sites in the Philippines and sacred forests of Kenya.

- Resource catchment areas, from which communities make their essential livelihoods or from which key ecosystem benefits are derived, managed in such a way that these benefits are sustained over time. For example, locally managed marine areas in the South Pacific and Madagascar, autonomous marine protected areas and Satoumi seascapes in Japan, marine areas for responsible fishing in Costa Rica, and community forests in Tanzania.
- Areas conserved for optimising productivity of related ecosystems-for example, 'fisher forests' or 'fish-breeding forests' in Japan.

- Areas and species populations sustainably managed for commercial benefits-for example, sites managed for ecotourism in Suriname and Kenya and areas managed for sustainable hunting and ecotourism like Namibia's Communal Conservancies.

- Nesting or roosting sites, other critical habitats of wild plants and animals, or wildlife populations spread over large territories, conserved for ethical or other reasons explicitly oriented towards protecting these plants and animals. For example, bird nesting and roosting sites in India, sacred crocodile ponds of Gambia and Mali, certain tree species like arawone (Tabebuia serratifolia) in Suriname and marine turtle nesting sites in Chile, Costa Rica and Suriname.

Source: Kothari et al. (2012) 


\section{Box 2.3 Values and benefits of ICCAs}

ICCAs, many of which a formally recognised as protected areas, include important values and provide many benefits including:

- providing the context and means for the sociocultural, economic, political, spiritual, and physical wellbeing of thousands of indigenous peoples and local communities, involving hundreds of millions of people

- helping to conserve critical ecosystems and threatened species across a broad range of biogeographic regions of the world

- maintaining essential ecosystem functions, such as water security, soil conservation and maintenance of gene pools

- providing connectivity conservation corridors and linkages for species movements including often between two or more protected areas

- providing secure and sustainable (though not necessarily adequate in all cases) livelihoods in a variety of occupations-both subsistence and revenue-generating-including forestry, fisheries, pastoralism, crafts, health, tourism and others

- helping to conserve a diversity of agricultural ecosystems, species/genes, and practices, as well as synergising links between agricultural biodiversity and wildlife and providing larger land and waterscapelevel integration for conservation

- offering crucial lessons for participatory governance that are useful for providing guidance for every form of governance including government-managed protected areas

- offering lessons in integrating customary and statutory laws, and formal and non-formal institutions that aim to achieve effective conservation

- building on and validating sophisticated local ecological knowledge systems, elements of which have wider positive use
- aiding communities with resistance to destructive development and saving territories and habitats from mining, dams, logging, tourism, over-fishing, agricultural expansion by settler populations, and others

- helping communities in empowering themselves, especially to reclaim or securing territories, tenure and rights to or control over resources they depend on or relate to

- aiding communities to better define their territories, such as through mapping

- helping to create a greater sense of community identity and cohesiveness, and also a renewed vitality and sense of pride in local cultures including amongst youth who may otherwise be alienated through modern influences

- creating conditions for other developmental inputs to flow into the community such as funds for schools, health clinics, water connections and livelihood enterprises

- leading to greater equity within a community (e.g. between classes, men and women, and ethnic groups) and between the community and outside agencies (e.g. in decision-making)

- conserving biodiversity at relatively low financial cost (though often high labour inputs), with costs of management often covered as part of normal livelihood or cultural activities, through existing systems and structures

- providing examples of relatively simple and effective administration and decision-making structures, and avoiding complex bureaucracies.

Values and benefits of protected areas are discussed further in Chapter 6.

Source: Kothari et al. (2012)
The Aichi Target 11 of the CBD recognises that if the global goal of 17 per cent terrestrial and 10 per cent marine coverage of conservation is to be achieved, it will have to be through a combination of protected areas and 'other effective area-based conservation measures', such as the examples above.

\section{Challenges for protected areas}

Protected area governance authorities and managers (Box 2.4) have enormous challenges in the 21st century. The footprint of human disturbance and change can be seen on every continent of Earth including Antarctica, and transformation of natural environments has gained momentum, not diminished during this century. Assessments of the challenges facing protected areas made by Charles Barber and his colleagues in 2004 are essentially unchanged (Barber et al. 2004), though they are perhaps clearer in 2014, such as the increasingly entrenched effects of climate change (IPCC 2013) and population growth, which could see 9.2 billion people on Earth in 2050 (UNEP 2013). In this book we appraise such underlying causes of threats to protected areas (Chapter 16) and provide responses to the consequent challenges facing protected area governors and managers. Our aim is to equip protected area practitioners with the information they need to achieve effective management of their areas as a basis for creating improved futures 


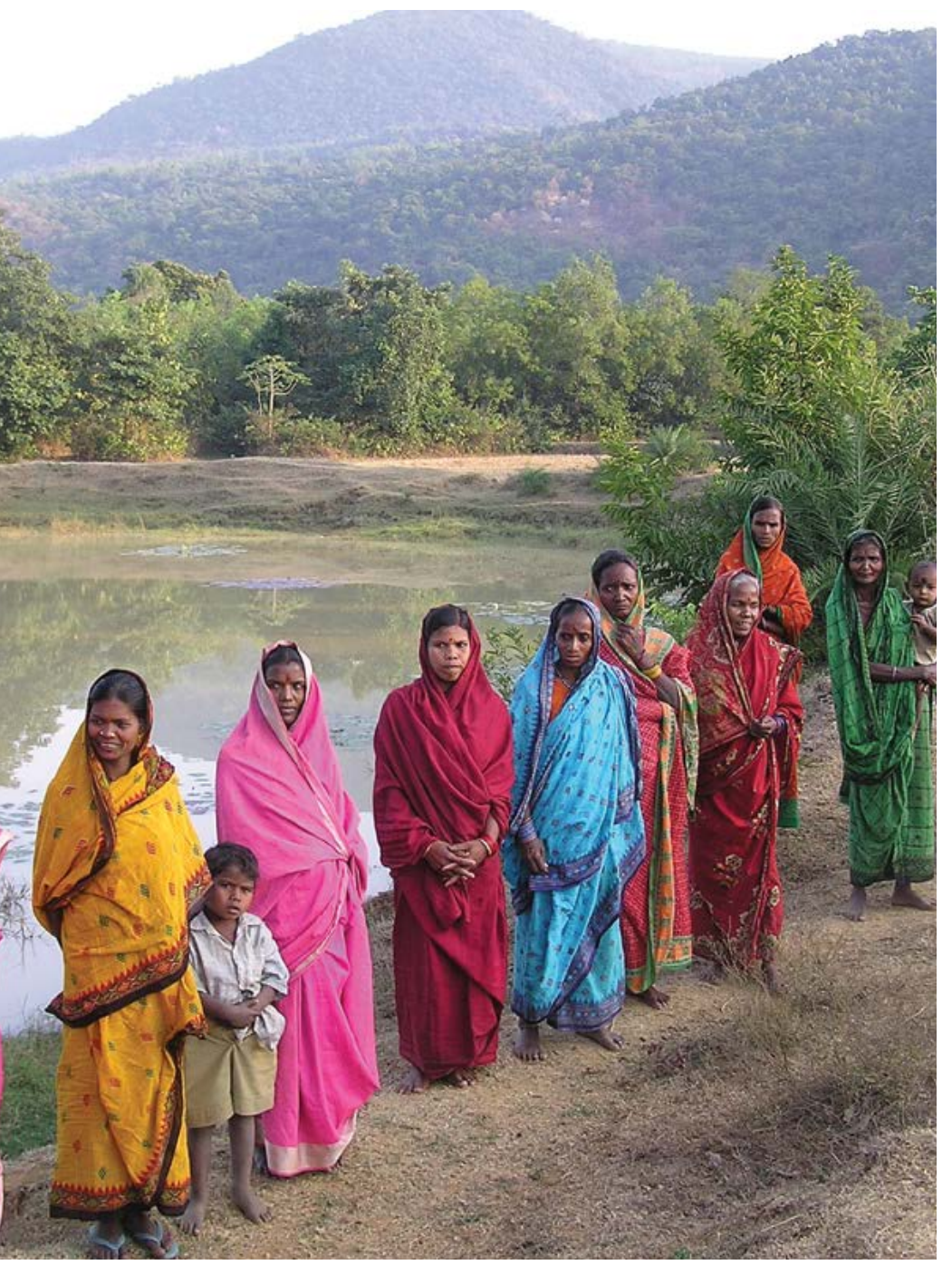

Women's forest protection committee at Dangejheri village, Odisha, India

Source: Ashish Kothari

for species, ecosystems and other heritage and for maintaining healthy environments and consequently healthy people on our planet. Here we briefly consider some significant challenges and introduce the book chapters that respond to these issues. These challenges below comprise facts, observations by many people and some personal reflections based on the author's 40 years of protected area professional management.

\section{Challenge: Global change}

Global change is a major challenge for protected area governors and managers. In the 21 st century they will need to deal with a shifting climate with its associated more frequent and more severe storm and weather systems; with sea-level rise and the inundation of islands, and estuarine and low-lying areas; and with the melting of many mountain glaciers and the transformation of

\section{Box 2.4 Governance and management}

Governance is a critical part of protected areas that identifies how organisations administer a protected area and the associated power and decision-making arrangements. It addresses who makes decisions for protected areas and their management, and how the decisions are made. It is different from management that focuses on what responses are needed for a given situation or a location in need of attention. Governance is about how power is exercised, how decisions are taken on issues of public concern and how citizens or other stakeholders have their say (Graham et al. 2003). Global conservation policy has also recognised the importance of the quality of governance, including whether individual protected areas or the protected area system as a whole incorporate principles such as accountability, fairness, equity, participation, subsidiarity, effectiveness for achieving biodiversity conservation, and others. Chapter 7 discusses governance and protected areas in more detail.

Management is about the coordination of people, resources and activities to achieve the objectives of a protected area organisation (Hitt et al. 2011), and there are four basic functions that are undertaken in any process of management: planning, organising, leading and evaluating. Protected areas need active management for the conservation of biodiversity, other natural heritage and cultural heritage. If this management is not effective then a protected area may be reduced to being a 'paper park' with its heritage values lost. Chapter 8 of this book describes in more detail how protected areas are established and managed and Chapter 28 describes the concept of management effectiveness evaluation. perennial streams to ephemeral streams (Chapter 17). These changes will see enhanced threats from droughts, flooding rains and incidents such as wildfire, and the effects of storm surges will be more frequent and require new skills and responses for protected area professionals (Chapter 26). These climate change trends will also witness shifts in areas suitable for vegetation types, changes in habitats and invasions of alien species that will require more strategic, more frequent and often larger and more sophisticated management responses (Chapter 16).

It will be a world of increasing human population and associated increasing demand for Earth's finite resources, enhanced industrialisation, globalised commerce, instant communication, and the resulting transformation and reduction in area of natural habitats and impacts on Earth's species (Barber et al. 2004). Increased tension and conflict are potentially major issues as human demands 
and industries endeavour to access existing protected areas and threats from outside park boundaries impact on the health of the ecosystems and species. Pollution of the atmosphere, creeks, rivers, estuaries and oceans can be expected to increase and other threats such as habitat destruction and poaching can be expected to prevail given more people on Earth (Barber et al. 2004). Some issues may be amenable to global responses such as acceptance of a broadscale international ban on mining in protected areas (Categories $\mathrm{I}-\mathrm{V}$ ) in accordance with the 21 st-century IUCN position. Other issues may be suitable for protected area system-level responses where governments, organisations and communities vigorously and faithfully uphold the IUCN protected area category objectives of management. Many issues, however, will need to be dealt with as they impact individual protected areas.

The pressures of some commerce, business sectors and agriculture on society to move substantially away from conservation and protection in favour of utilisation and development will increase. Forces advocating and facilitating the 'regression' and 'back-sliding' of protected areas for 'use' and for vested interests may grow as populations grow and as resources become scarce. In different parts of the world, the equivalent of the 1913 Hetch Hetchy Dam 'utilisation versus conservation' debate in Yosemite National Park in the United States could occur. In 1912, John Muir wrote:

Hetch Hetchy is a grand landscape garden, one of nature's rarest and most precious mountain temples. As in Yosemite, the sublime rocks of its walls seem to glow with life ... while birds, bees, and butterflies help the river and waterfalls to stir all the air into music ... These temple destroyers, devotees of ravaging commercialism, seem to have a perfect contempt for Nature, and, instead of lifting their eyes to the God of the mountains, lift them to the Almighty Dollar. (Muir 1912)

Thankfully in the 21st century, people like Muir continue to inspire and seek to conserve protected areas for future generations. Part of this inspiration is the knowledge that if these areas are utilised and despoiled, there will be few (if any) remaining equivalent lands on finite Earth. Their intergenerational inheritance status, their long-term immense and sustainable contribution to ecosystem services, their purpose in protecting a nation's species, their role in retaining healthy environments and their natural beauty are what is enjoyed so much by people (Chapter 6).
Leadership and effective governance and management of protected areas will need to anticipate and deal with 'use' advocacy pressures (Chapters 7, 8 and 12). The concept of protected areas as intergenerational or 'forever protected' lands will need to be deeply valued by all societies. It will need to be constantly championed. Protected area leaders (Chapter 12) will need to effectively communicate protection messages (Chapter 15), work positively with people and decision-makers (Chapter 14) and ensure that information about the importance and benefits of protected areas is readily available (Chapter 11). Dealing with the larger issue of the sustainable use of Earth's finite resources will be a critical part of helping to protect the natural values of protected areas in the long term (Chapter 8).

\section{Challenge: Establishing new protected areas}

Protected area governors and managers have the comfort and knowledge that well-managed protected areas are effective in their role of protecting individual species, biodiversity and ecosystem services and other natural and cultural heritage. In 2014, however, there is inadequate coverage of protected areas on Earth. Only 15.4 per cent of the Earth's terrestrial area (outside Antarctica) and 3.4 per cent of its marine environment are under officially recognised protected areas (IUCN and UNEP-WCMC 2014), and this is not enough to adequately conserve Earth's species. This challenge was identified by the Convention on Biological Diversity strategic plan 2011-20 and especially Target 11:
By 2020, at least 17 per cent of terrestrial and inland water areas, and 10 per cent of coastal and marine areas, especially areas of particular importance for biodiversity and ecosystem services, are conserved through effectively and equitably managed, ecologically representative and well-connected systems of protected areas and other effective area-based conservation measures, and integrated into the wider landscapes and seascapes. (CBD 2011:3)

Consequently, nations of Earth have agreed that additional protected areas need to be established, and recognition provided to currently unrecognised conservation initiatives by communities and the private sector to fill gaps. Establishing exactly where new protected areas are needed is critical, and a gap analysis supported by systematic conservation planning approaches is often used to achieve this (Chapter 13). In 


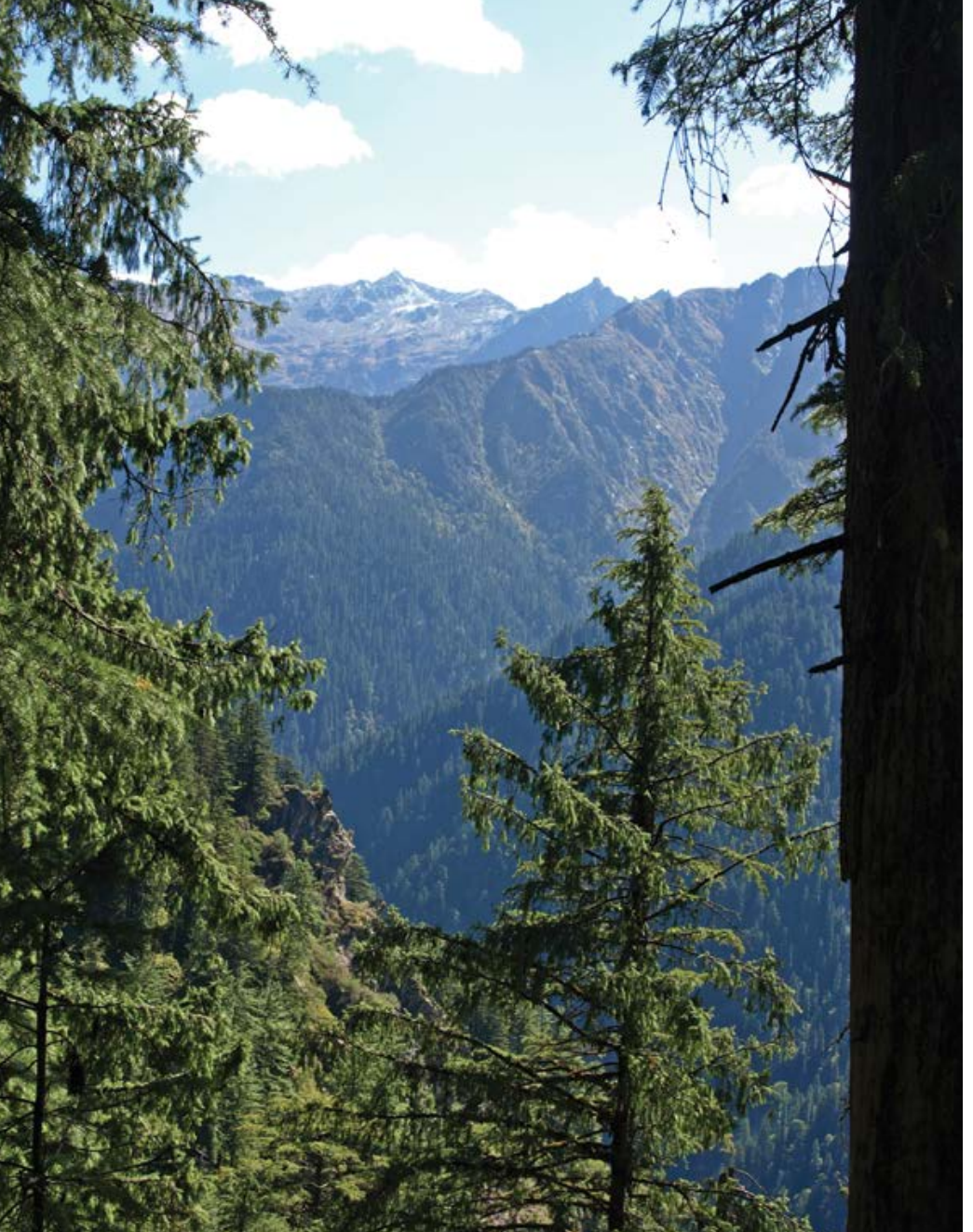

Great Himalayan National Park, India

Source: Graeme L. Worboys

2014, more sophisticated data aggregation approaches are also being used to identify key biodiversity areas (Chapter 21).

The introductory descriptions of the Earth's major environment types (Chapter 3) underpin more detailed identification of terrestrial areas that represent important biodiversity areas and potential gaps of biodiversity conservation significance (Chapters 3 and 21; Butchart et al. 2012). Consideration of cultural heritage (Chapter 4), geoheritage (Chapter 18), freshwater and estuarine environments (Chapter 19) and marine environments (Chapter 20) helps identify the importance of conserving natural and cultural heritage. Establishing the locations, purposes and management objectives is an important part of the reservation process, and the six universally accepted IUCN categories described above provide essential guidance in this regard. Visionary leadership is also a key part of establishing new protected areas (Chapter 12), as is a clear understanding of the social and political contexts and societal influences and global change (Chapter 5).

\section{Challenge: Effective governance and management}

The practice of protected area governance and management is an essential profession for facilitating a healthy environment and for helping to conserve life on Earth. Ideally it is underpinned by both formal tertiarylevel protected area governance and management qualifications and vocation-based training (Chapter 9), and achieving this standard is a global challenge. Local traditional knowledge held by indigenous communities also provides a critical contribution to conservation management (Chapters 7 and 25).

Achieving effective governance for protected areas is vital (Chapter 7). Organisations and communities will need to be adaptive and responsive to changes, and local professional protected area managers will need to have the freedom to manage (Chapter 8), albeit within established statutory, corporate and planned guidelines, as well as with community input and guidance. The imposition of directives from centralised power bases, for example, which disempowers the ability of 'managers to manage' and otherwise protect nature, is poor governance practice and a threat to nature conservation.

In addition to staff with the right competencies and training, effective management is based on good planning (Chapter 13), good business management, a sound knowledge of managing biodiversity conservation needs (Chapter 21), the ability to manage for cultural heritage management requirements (Chapter 22), resource use (Chapter 25) and operations management (Chapter 24), as well as looking after the needs of visitors (Chapter 23). This important work may extend to managing World Heritage properties (Chapter 3) or working off-reserve or conservation area to help facilitate connectivity conservation areas (Chapter 27). Evaluating the effectiveness of all of this professional management activity and reporting on the good work are fundamental for the future (Chapter 28). Achieving a minimum professional standard of protected area governance and management for all protected areas on Earth provides a fundamental contribution to the conservation of life on Earth. It is a formidable challenge in the early part of the 21 st century, with this book providing one response to this challenge.

\section{Challenge: The future}

Protected areas provide a key response to many of the environmental issues facing all nations of Earth in the coming decades and in particular climate change, water stress, food security, energy production and biodiversity 
loss (MacKinnon et al. 2011). They have a formidable responsibility, for protected areas are the principal tools for conserving Earth's diversity of life and for protecting a wealth of natural and cultural heritage on behalf of nations. The concept of protected areas has been implemented with confidence by governments and others since the 20th century, and science has confirmed that effectively managed protected areas have been successful in conserving biodiversity. As we progress further and further into the 21 st century, with its associated human population increases, development and consumption, deepening impacts of climate change, post-peak oil energy changes, resource shortages and potential social disorder, there will be increasing challenges for protected areas and their managers. The actions in the 20th and early 21 st centuries to reserve and establish protected areas, though formidably tough to achieve, will in retrospect be seen as the easy (though essential) part of the history of governing and managing for protected areas.

In the future, protected areas may well be among the last natural lands. If so, they would be a focus of attention. They would be the only places where certain resources were available and where the last of some species continued to exist in the wild. Knowing human behaviour, one inevitable threat would be in the form of the seemingly irresistible forces that seek to access and utilise (either legally or illegally) the last of these resources, despite the consequences. The illegal shooting of rhinoceros for their horns in Kruger National Park, South Africa, in 2013 to meet the demand from Asian medicine markets (irrespective of the decline in rhinoceros population numbers) is one example of such a potential future. Mining is another formidable threat. It is currently one of the severest threats to protected areas and even to World Heritage sites, for income from mining royalties is hard for economically struggling economies to resist.

We need to be optimistic that planet Earth and its peoples will never allow a situation where short-term resource gains have precedence over lands and seas protected for their outstanding values for all generations. We need to invest in a healthy planet where the diversity of life can continue, and where the natural inheritance of future generations is held in trust and effectively managed. There is no doubt, however, that protected area managers will be challenged more and more in the future. These challenges will come from many environmental threats as well as the social and political contexts in which protected areas operate. This book has been designed to help equip 21 st-century protected area managers to deal with such issues and to provide the type of leadership necessary to help secure protected areas as long-term treasured assets of the community that are 'too precious to lose'.

\section{Conclusion}

The 20th century and the first part of the 21st century have witnessed one of the great peaceful land-use and sea-use transformations in human history with the establishment of protected areas by nearly all nations of Earth, although this action is unfinished and ongoing. In 2014, protected areas covered 15.4 per cent of the terrestrial area of Earth, 3.4 per cent of the sea and 8.4 per cent of seas under national jurisdiction (IUCN and UNEP-WCMC 2014). The urgency of protected area establishment is one critical response to today's challenges and those of the future, including threats from habitat loss and climate change.

The Convention on Biological Diversity's 'Strategic Plan for Biodiversity 2011-20' (CBD 2011) challenges nations to achieve protected area (and other effective area-based conservation area) targets of at least $17 \%$ for terrestrial areas and $10 \%$ for marine areas by 2020 . This reflects great confidence in the concept of protected areas as a critical conservation tool. Such confidence is based on lived experience and demonstrated conservation successes. It is also confidence achieved through the clarity of purpose for protected areas that is underpinned by robust supporting information. Protected areas are clearly defined; the different management types are formally recognised including six IUCN management categories; their different governance types are formally described; and the principles of their management are clearly articulated. Protected areas are also effective thanks to planned, active and competent management implemented by trained practitioners. Protected areas help conserve biodiversity and other natural heritage and cultural heritage and they are an intergenerational investment in a better world.

\section{Supplementary reading}

The IUCN has produced a suite of important guidelines and other protected area governance and management literature, many of which are listed in Appendix 2.1. 


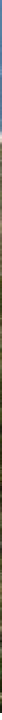

Cape Point, Cape of Good Hope section, Table Mountain National Park, South Africa: the park includes Cape Flora vegetation communities, one of the world's richest temperate flora that includes fynbos (shrubland that is dominated by fine-leaved shrubs). The park is part of the Cape Floral Region Serial World Heritage Property.

Source: Graeme L. Worboys

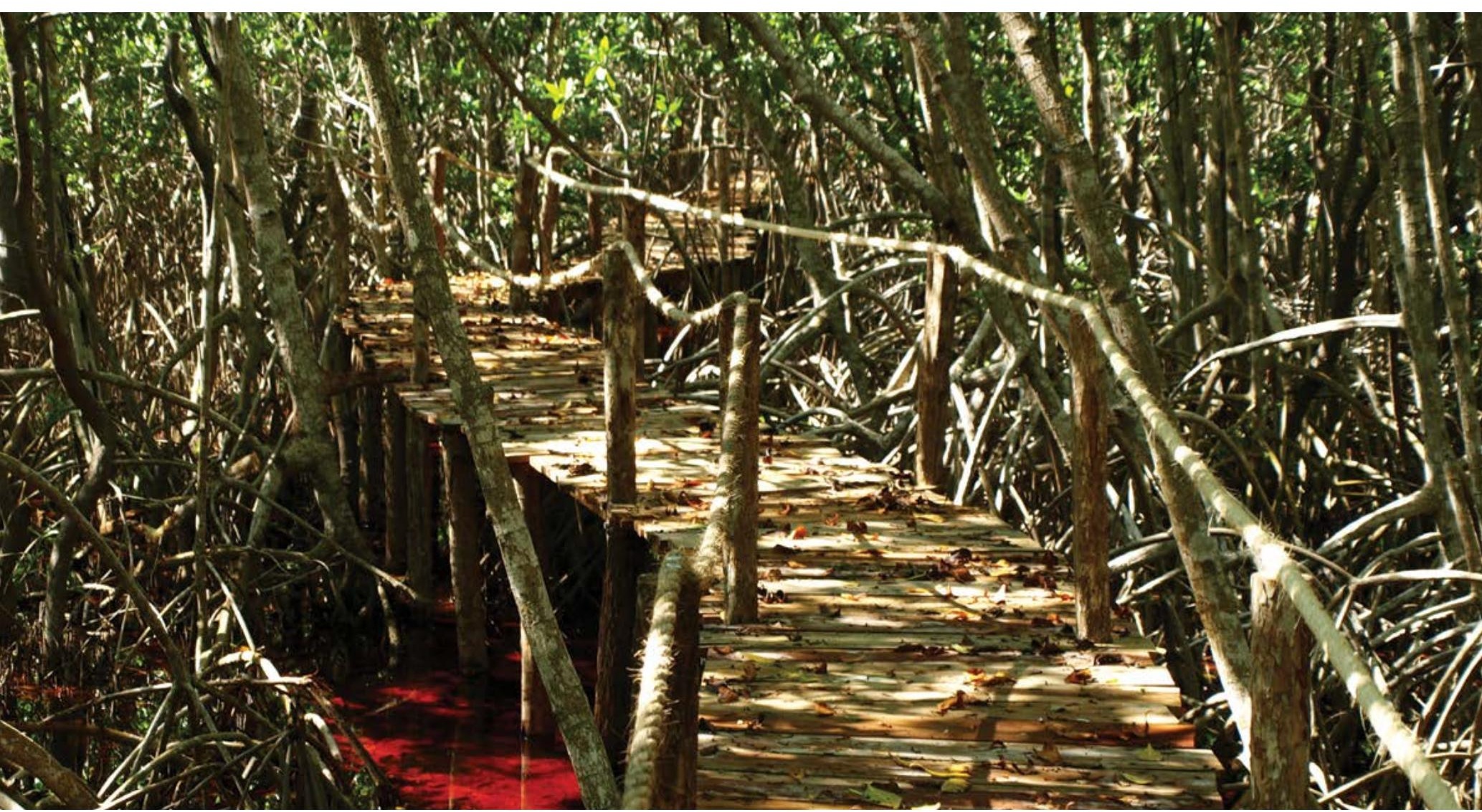

The boardwalk shown provides visitor access through rich mangrove communities within the Celestun Biosphere Reserve, Yucatan State, Mexico: the fresh water cenotes, mangrove and estuarine habitats of the reserve help to protect flocks of flamingos (Phoenicopterus sp.) and herons; it is an important resting and breeding site for migratory birds and it is a hatching ground for turtle species.

Source: Graeme L. Worboys 


\section{References}

Recommended reading

Ali, S. (ed.) (2007) Peace Parks, Conservation and Conflict Resolution, MIT Press, Cambridge, Mass.

Amend, T., Brown, J., Kothari, A., Phillips, A. and Stolton, S. (eds) (2008) Protected Landscapes and Agrobiodiversity Values. Volume 1, Values of Protected Landscapes and Seascapes Series, IUCN WCPA Specialist Group on Protected Landscapes and GTZ on behalf of the Federal Ministry of Economic Cooperation and Development of Germany, Heidelberg.

Barber, C. V., Miller, K. R. and Boness, M. (eds) (2004) Securing Protected Areas in the Face of Global Change: Issues and strategies, IUCN WCPA, Gland.

Beltrán, J. (ed.) (2000) Indigenous and Traditional Peoples and Protected Areas: Principles, guidelines and case studies, IUCN, Gland.

Bennett, A. F. (2003) Linkages in the Landscape: The role of corridors and connectivity in wildlife conservation, 2nd edn, IUCN Forests Program, Gland.

Bennett, G. (2004) Integrating Biodiversity Conservation and Sustainable Use: Lessons learned from ecological networks, IUCN, Gland.

Bernbaum, E. (1990) Sacred Mountains of the World, Sierra Club and University of California Press, Berkeley.

D Bertzky, B., Corrigan, C., Kemsey, J., Kenney, S., Ravilious, C., Besançon, C. and Burgess, N. (2012) Protected Planet Report 2012: Tracking progress towards global targets for protected areas, UNEPWCMC, Cambridge.

Bertzky, B., Shi, Y., Hughes, A., Engels, B., Ali, M. K. and Badman, T. (2013) Terrestrial Biodiversity and the World Heritage List: Identifying broad gaps, and potential candidate sites for inclusion in the Natural World Heritage network, IUCN, Gland, and UNEP-WCMC, Cambridge.

Bishop, K., Dudley, N., Phillips, A. and Stolton, S. (2004) Speaking a Common Language: The uses and performance of management categories for protected areas, IUCN, Gland.
Borrini-Feyerabend, G., Dudley, N., Jaeger, T., Lassen, B., Pathak Broome, N., Phillips, A. and Sandwith, T. (2013) Governance of Protected Areas: From understanding to action, Best Practice Series No. 20, IUCN, Gland.

Borrini-Feyerabend, G., Kothari, A. and Oviedo, G. (2004) Indigenous and Local Communities and Protected Areas: Towards equity and enhanced conservation, IUCN, Gland.

Braack, L., Sandwith, T., Peddle, D. and Petermann, T. (2006) Security Considerations in the Planning and Management of Transboundary Conservation Areas, WCPA Task Force on Transboundary Conservation, IUCN, Gland.

Brockman, C. F. (1959) Recreational Use of Wild Lands, McGraw Hill, New York.

Brown, J., Mitchell, N. and Beresford, M. (eds) (2005) The Protected Landscape Approach: Linking nature, culture and community, IUCN WCPA, Gland.

Butchart, S. H. M., Scharlemann, J. P. W., Evans, M. I., Quader, S., Aricò, S., Arinaitwe, J., Balman, M., Bennun, L. A., Bertzky, B., Besançon, C., Boucher, T., Brooks, T. M., Burfield, I. J., Burgess, N. D., Chan, S., Clay, R. P., Crosby, M. J., Davidson, N. C., de Silva, N., Devenish, C., Dutson, G. C. L., Fernández, D. F. D. z., Fishpool, L. D. C., Fitzgerald, C., Foster, M., Heath, M. F., Hockings, M., Hoffmann, M., Knox, D., Larson, F. W., Lamoreux, J. F., Loucks, C., May, I., Millett, J., Molloy, D., Morling, P., Parr, M., Ricketts, T. H., Seddon, N., Skolnik, B., Stuart, S. M., Upgren, A. and Woodley, S. (2012) 'Protecting important sites for biodiversity contributes to meeting global conservation targets', PLoS ONE 7(3): e32529.

Campbell, C. (ed.) (2011) A Century of Parks Canada, 1911-2011, University of Calgary Press, Calgary.

Catlin, G. (1844) 'Letter No. 31', Letters and Notes on the Manners, Customs and Condition of the North American Indians, Wiley \& Putnam, New York. $<$ user.xmission.com/ - drudy/mtman/html/catlin/>

Ceballos-Lascuráin, H. (1996) Tourism, Ecotourism and Protected Areas, Protected Areas Programme, IUCN, Gland.

Chape, S., Blyth, L., Fish, P. and Spalding, M. (2003) 2003 United Nations List of Protected Areas, IUCN, Gland, and UNEP-WCMC, Cambridge. 
DD Chape, S., Spalding, M. and Jenkins, M. (2008) The World's Protected Areas: Status, values and prospects in the 21st century, University of California, Berkeley.

Commission on National Parks and Protected Areas (CNPPA) (1994) Guidelines for Protected Area Management Categories, IUCN, Gland.

Convention on Biological Diversity (CBD) (2011) Strategic Plan for Biodiversity 2011-2020 and the Aichi Targets, Secretariat of the Convention on Biological Diversity, Montreal. <www.cbd.int/sp/ targets/default.shtml>

Davey, A. G. (1998) National System Planning for Protected Areas, IUCN, Gland.

DD Dudley, N. (2008) Guidelines for Applying Protected Area Management Categories, IUCN, Gland.

Dudley, N. and Phillips, A. (2006) Forests and Protected Areas: Guidance on the use of the IUCN protected area management categories, IUCN WCPA, Gland.

Dudley, N. and Stolton, S. (eds) (2012) Protected Landscapes and Wild Biodiversity. Volume 3, Values of Protected Landscapes and Seascapes Series, IUCN WCPA Specialist Group on Protected Landscapes, Gland.

DD Dudley, N., Stolton, S., Belokurov, A., Krueger, L., Lopoukhine, N., MacKinnon, K., Sandwith, T. and Sekran, N. (eds) (2010) Natural Solutions: Protected areas helping people cope with climate change, IUCN WCPA, The Nature Conservancy and Wildlife Conservation Society, Gland; The World Bank, Washington, DC; UNDP and WWF, New York.

Eagles, P. F. J., McCool, S. F. and Haynes, C. D. (2002) Sustainable Tourism in Protected Areas: Guidelines for planning and management, IUCN, Gland.

Emerton, L., Bishop, J. and Thomas. L. (2006) Sustainable Financing of Protected Areas: A global review of challenges and options, IUCN WCPA, Gland.

Figgis, P. (2012) 'Innovation in conservation', in P. Figgis, J. Fitzsimons and J. Irving (eds) Innovation for 21st Century Conservation, pp. 10-15, Australian Committee for IUCN, Sydney.
Figgis, P. and Koss R. (eds) (2012) Conserving Australia's Marine Environment: Key directions statement, Australian Committee for IUCN, Sydney.

Figgis, P., Leverington, A., Mackay, R., Maclean, A. and Valentine, P. (2013) Keeping the Outstanding Exceptional: The future of world heritage in Australia, Australian Committee for IUCN, Sydney.

Finlayson, B. and Hamilton-Smith, E. (2003) Beneath the Surface: A natural history of Australian caves, UNSW Press, Sydney.

Government of Australia (2013) Indigenous Protected Areas, Australian Government, Canberra. <www. environment.gov.au/indigenous/ipa/>

Graham, J., Amos, B. and Plumptre, T. (2003) Governance principles for protected areas in the 21st century, Paper prepared for the Fifth World Parks Congress, Durban, South Africa, Institute of Governance, Ottawa.

Grove, R. (1995) Green Imperialism: Colonial expansion, tropical island Edens and the origins of environmentalism, 1600-1860, Cambridge University Press, Cambridge.

Dd Hamilton, L. and McMillan, L. (2004) Guidelines for Planning and Managing Mountain Protected Areas, IUCN WCPA, Gland.

Hamilton, L. S., Bauer, D. and Takeuchi, H. F. (1993) Parks, Peaks and People: A collection of papers arising from an international consultation on protected areas in mountain environments held in Hawaii Volcanoes National Park 26 October - 2 November 1991, East West Centre Program on Environment, IUCN Commission on National Parks and Protected Areas, Woodlands Mountain Institute and US National Parks Service, Honolulu.

Hamilton, L. S., Mackay, J. C., Worboys, G. L., Jones, R. A. and Manson, G. B. (1996) Transborder Protected Area Cooperation, Australian Alps Liaison Committee, Canberra.

Harmon, D. and Putney, A. D. (2003) The Full Value of Parks: From economics to the intangible, Rowman \& Littlefield, New York.

Harmon, D. and Worboys, G. L. (eds) (2004) Managing Mountain Protected Areas: Challenges and responses for the 21st century, IUCN WCPA, Andromeda Editrice, Colledara, Italy. 
Hitt, M. A., Black, S. and Porter, L. W. (2011) 'The nature of management', in A. Jayawardana (ed.) Management and Organisations, pp. 4-28, Pearson Australia, Sydney.

Hockings, M., Stolton, S. and Dudley, N. (2000) Evaluating Effectiveness: A framework for assessing the management of protected areas, No. 6, IUCN, Gland.

Dd Hockings, M., Stolton, S., Leverington, F., Dudley, N. and Courrau, J. (2006) Evaluating Effectiveness: A framework for assessing management effectiveness of protected areas, 2 nd edn, No. 14, IUCN WCPA, Gland.

Holdgate, M. (1999) The Green Web: A union for world conservation, Taylor \& Francis, London.

Hornback, K. E. and Eagles, P. F. J. (1999) Guidelines for Public Use Measurement and Reporting at Parks and Protected Areas, IUCN, Gland.

Intergovernmental Panel on Climate Change (IPCC) (2013) Climate Change 2013: The physical science basis_Headline statements for policy makers, Intergovernmental Panel on Climate Change, Geneva. <www.ipcc.ch/>

International Union for Conservation of Nature (IUCN) (1992) Protected Areas of the World: A review of national systems. Volume 1: Indomalaya, Oceania, Australia and Antarctic, IUCN, Gland and Cambridge.

International Union for Conservation of Nature (IUCN) (1994a) Guidelines for Protected Area Management Categories, IUCN, Gland and Cambridge.

International Union for Conservation of Nature (IUCN) (1994b) Parks for Life: Action for protected areas in Europe, IUCN, Gland.

International Union for Conservation of Nature (IUCN) (1995) African Heritage 2000: The future of protected areas in Africa, IUCN, Gland.

International Union for Conservation of Nature (IUCN) (2005) Benefits beyond Boundaries: Proceedings of the Vth IUCN World Park's Congress, IUCN, Gland.

International Union for Conservation of Nature (IUCN) (2010) 50 Years of Working for Protected Areas: A brief history of the IUCN World Commission on Protected Areas, IUCN, Gland.
International Union for Conservation of Nature, United Nations Environment Programme and World Wildlife Fund (IUCN/UNEP/WWF) (1980) World Conservation Strategy: Living resource conservation for sustainable development, IUCN, UNEP and WWF, Gland.

International Union for Conservation of Nature, United Nations Environment Programme and World Wide Fund for Nature (IUCN/UNEP/ WWF) (1991) Caring for the Earth: A strategy for sustainable living, IUCN, UNEP and WWF, Gland.

International Union for Conservation of Nature (IUCN) and United Nations Environment Programme World Conservation Monitoring Centre (UNEP-WCMC) (2014) The World Database on Protected Areas: August 2014, UNEP-WCMC, Cambridge.

1 Keenleyside, K., Dudley, N., Cairns, S., Hall, C. and Stolton, S. (2012) Ecological Restoration for Protected Areas: Principles, guidelines and best practices, No. 18, IUCN WCPA Ecological Task Force, Gland.

Kelleher, G. (1999) Guidelines for Marine Protected Areas, No. 3, IUCN, Gland.

Kelleher, G. and Kenchington, R. (1992) Guidelines for Establishing Marine Protected Areas, IUCN, Gland.

Kopylova, S. L. and Danilina, N. R. (eds) (2011) Protected Area Staff Training: Guidelines for planning and management, No. 17, IUCN WCPA, Gland.

Kothari, A. (2006) 'Community conserved areas: towards ecological and livelihood security', Parks 16(1): 3-13.

Dd Kothari, A., Corrigan, C., Jonas, H., Neumann, A. and Shrumm, H. (eds) (2012) Recognising and Supporting Territories and Areas Conserved by Indigenous Peoples and Local Communities: Global overview and national case studies, Secretariat of the Convention on Biological Diversity, CBD Technical Series No. 64, ICCA Consortium, Kalpavriksh and Natural Justice, Montreal. 
Langhammer, P. F., Bakarr, M. I., Bennun, L. A., Brooks, T. M., Clay, R. P., Darwall, W., de Silva, N., Edgar, G. J., Eken, G., Fishpool, L. D. C., da Fonseca, G. A. B., Foster, M. N., Knox, H. D., Matiku, P., Radford, E. A., Rodriques, A. S. L., Salaman, P., Sechrest, W. and Tordoff, A. W. (2007) Identification and Gap Analysis of Key Biodiversity Areas: Targets for comprehensive protected area systems, No. 15, IUCN WCPA, Gland.

Langholz, J. (2005) 'Seven myths about private protected areas', Parks 15(2): 14-16.

Lausche, B. (2011) Guidelines for Protected Area Legislation, IUCN, Gland.

Lausche, B., Farrier, D., Verschuuren, J., La Vina, A. G. M., Trouwborst, A., Born, C.-H. and Aug, L. (2013) The Legal Aspects of Connectivity Conservation: A concept paper, IUCN, Gland.

Lockwood, M. (2006) 'Values and benefits', in M. Lockwood, G. L. Worboys and A. Kothari (eds) Managing Protected Areas: A global guide, pp. 10115, Earthscan, London.

Lockwood, M., Worboys, G. L. and Kothari, A. (2006) Managing Protected Areas: A global guide, Earthscan, London.

MacKinnon, K., Dudley, N. and Sandwith, T. (2011) 'Natural solutions: protected areas helping people to cope with climate change', Oryx 45(4): 461-2.

Mackinnon, K., Mackinnon, J., Child, G. and Thorsell, J. (1986) Managing Protected Areas in the Tropics, IUCN, Gland and Cambridge.

Mallarach, J.-M. (ed.) (2008) Protected Landscapes and Cultural and Spiritual Values. Volume 2, Values of Protected Landscapes and Seascapes Series, IUCN WCPA Specialist Group on Protected Landscapes, GTZ and Obra Social de Caixa Catalunya, Kasparek Verlag, Heidelberg.

Mallarach, J.-M. and Papayannis, T. (eds) (2007) Protected Areas and Spirituality: Proceedings of the first workshop of the Delos Initiative, IUCN WCPA Task Force on Cultural and Spiritual Values of Protected Areas, Gland, and Publicacions de l'Abadia de Montserrat, Montserrat.

Muir, J. (1912) 'Hetch Hetchy Valley', in The Yosemite, Century, New York. <www.sierraclub.org/john_ muir_exhibit/writings/the_yosemite/>
Pathak, N. (2009) Community Conserved Areas in India-A directory, Kalpavriksh, Pune, India.

Phillips, A. (2002) Management Guidelines for Category V Protected Areas: Protected landscapes/seascapes, No. 9, IUCN WCPA, Gland.

Poore, D. (ed.) (1992) Guidelines for Mountain Protected Areas, IUCN Protected Area Programme Series No. 2, Gland.

Ramsar (2013) Introduction to Ramsar. <www.ramsar. org/cda/en/ramsar-home/main/ramsar/1_4000_0>

Rose, B. (2013) 'Indigenous protected areasinnovation beyond the boundaries', in P. Figgis, J. Fitzsimons and J. Irving (eds) Innovation for 21st Century Conservation, pp. 50-55, Australian Committee for IUCN, Sydney.

Sandwith, T., Shine, C., Hamilton, L. and Sheppard, D. (2001) Transboundary Protected Areas for Peace and Co-Operation, No. 7, IUCN, Gland.

Stolton, S. (2010) 'Protected areas: linking environment and well-being', in S. Stolton and N. Dudley (eds) Arguments for Protected Areas: Multiple benefits for conservation and use, pp. 1-12, Earthscan, London.

Stolton, S. and Dudley, N. (2010) Arguments for Protected Areas: Multiple benefits for conservation and use, Earthscan, London.

Taylor, M. and Figgis, P. (2007) Protected Areas: Buffering nature against climate change. Proceedings of a WWF and IUCN World Commission on Protected Areas Symposium, 18-19 June 2007, Canberra, WWF Australia, Sydney.

Thomas, L. and Middleton, L. (2003) Guidelines for Management Planning of Protected Areas, No. 10, IUCN, Gland.

Thorsell, J. (ed.) (1990) Parks on the Borderline: Experience in transfrontier conservation, IUCN, Gland.

Theme on Indigenous and Local Communities Equity and Protected Areas and Theme on Governance, Equity and Rights (TILCEPA and TGER) (2008) Recognising and supporting indigenous and community conservation: ideas and experiences from the grassroots, CEESP Briefing Note 9, Commission on Environmental, Economic and Social Policy, IUCN, Gland. 
The Nature Conservancy (TNC) (2013) Vision and Mission, The Nature Conservancy, Arlington, VA. $<$ www.nature.org/about-us/vision-mission/index. htm>

Trzyna, T. (ed.) (2005) The Urban Imperative: Urban outreach strategies for protected area agencies, IUCN WCPA, Santa Monica Mountains Conservancy and InterEnvironment California Institute of Public Affairs, Sacramento.

Trzyna, T. (2014) Urban Protected Areas: Profiles and best practice guidelines, IUCN WCPA Best Practice Guideline No. 22, IUCN, Gland.

United Nations Environment Programme (UNEP) (2013) GEO-5: Environment for the future we want, Progress Press, Malta.

United Nations Environment Programme World Conservation Monitoring Centre (UNEP-WCMC) (1992) Protected Areas of the World: A review of national systems, (4 vols), IUCN, Gland.

United Nations Environment Programme (UNEP) (2007) Global Environmental Outlook Geo-5: Environment for development, UNEP, Nairobi.

United Nations Educational, Scientific and Cultural Organisation (UNESCO) (2002) Biosphere Reserves: On-ground testing for sustainable development, UNESCO Man and the Biosphere Program, GTOZ Print Investments, t/a Capture Press, South Africa.

United Nations Educational, Scientific and Cultural Organisation (UNESCO) (2010) Global Geoparks Network: Guidelines and criteria for national geoparks seeking UNESCO's assistance to join the Global Geoparks Network, UNESCO, Paris.

10 United Nations Educational, Scientific and Cultural Organisation (UNESCO) (2011) Operational Guidelines for the Implementation of the World Heritage Convention, UNESCO World Heritage Centre, Paris.

United Nations Educational, Scientific and Cultural Organisation (UNESCO) (2013a) World Heritage History, UNESCO, Paris. <whc.unesco.org/en/ convention/>

United Nations Educational, Scientific and Cultural Organisation (UNESCO) (2013b) Parties to the World Heritage Convention, UNESCO, Paris. <whc. unesco.org/en/statesparties/>
United Nations Educational, Scientific and Cultural Organisation (UNESCO) (2013c) Man and the Biosphere Program, UNESCO, Paris. <www. unesco.org/new/en/natural-sciences/environment/ ecological-sciences/man-and-biosphereprogramme/>

United Nations Educational, Scientific and Cultural Organisation (UNESCO) (2013d) Biosphere Reserve Designation Criteria, UNESCO, Paris. <www. unesco.org/new/en/natural-sciences/environment/ ecological-sciences/biosphere-reserves/designationprocess/>

United Nations Educational, Scientific and Cultural Organisation (UNESCO) (2013e) About Geoparks, UNESCO, Paris. <www.unesco.org/new/en/ natural-sciences/environment/earth-sciences/globalgeoparks/some-questions-about-geoparks/what-is-aglobal-geopark/>

United Nations Educational, Scientific and Cultural Organisation (UNESCO) (2014) What is the Global Geoparks Network?, UNESCO, Paris. <www.unesco. org/new/en/natural-sciences/environment/earthsciences/global-geoparks/some-questions-aboutgeoparks/what-is-a-global-geopark/>

Dd Vershuuren, B., Wild, R., McNeely, J. A. and Oviedo, G. (2010) Sacred Natural Sites: Conserving nature and culture, Earthscan, London.

Dd Watson, J., Hamilton-Smith, E., Gillieson, D. and Kiernan, K. (1997) Guidelines for Cave and Karst Protection, WCPA Working Group on Cave and Karst Protection, IUCN, Gland.

Wild, R. and McLeod, C. (2008) Sacred Natural Sites: Guidelines for protected area managers, No. 16, IUCN WCPA, Gland.

Worboys, G. L. (2014) Research completed for the preparation of the protected area governance and management book, Unpublished Protected Area Historical Research Paper, The Australian National University, Canberra.

Dd Worboys, G. L., Francis, W. and Lockwood, M. (2010) Connectivity Conservation Management: A global guide, Earthscan, London.

Worboys, G. L., Lockwood, M. and de Lacy, T. (2001) Protected Area Management: Principles and practice, Oxford University Press, Melbourne. 
Worboys, G. L., Lockwood, M. and de Lacy, T. (2005) Protected Area Management: Principles and practice, 2nd edn, Oxford University Press, Melbourne.

World Commission on Protected Areas (WCPA) (1998) Economic Values of Protected Areas: Guidelines for protected area managers, No. 2, Task Force on Economic Benefits of Protected Areas for the IUCN WCPA in collaboration with the Economic Service Unit of IUCN, Gland.

World Commission on Protected Areas (WCPA) (2000) Financing Protected Areas: Guidelines for protected area managers, No. 5, Financing Protected Areas Task Force, IUCN WCPA in collaboration with the Economics Unit of IUCN, Gland.

World Resources Institute, International Union for Conservation of Nature and United Nations Environment Programme (WRI/IUCN/UNEP) (1992) Global Biodiversity Strategy: Guidelines for action to save, study and use Earth's biotic wealth sustainably and equitably, IUCN, Gland. 


\section{Appendix 2.1}

\section{Key IUCN WCPA and related publications}

Please note: While every effort has been made in the research time available to identify key sources, this list is not complete.

\begin{tabular}{|c|c|c|}
\hline Year & Title & Reference \\
\hline \multicolumn{3}{|c|}{ 1973-82 } \\
\hline 1976 & Parks Magazine launched (produced volumes for a while) & Various \\
\hline 1980 & $\begin{array}{l}\text { World Conservation Strategy: Living resource conservation for sustainable } \\
\text { development }\end{array}$ & IUCN et al. (1980) \\
\hline \multicolumn{3}{|c|}{ 1983-92 } \\
\hline 1986 & Managing Protected Areas in the Tropics & Mackinnon et al. (1986) \\
\hline 1990 & Parks on the Borderline: Experience in transfrontier conservation & Thorsell (1990) \\
\hline 1991 & $\begin{array}{l}\text { The journal Parks recommenced (volumes produced until 2008, and then } \\
\text { recommenced in 2012) }\end{array}$ & Various \\
\hline 1991 & Caring for the Earth & IUCN et al. (1991) \\
\hline 1992 & Global Biodiversity Strategy & WRI et al. (1992) \\
\hline 1992 & Protected Areas of the World: A review of national systems (four volumes) & UNEP-WCMC and IUCN (1991) \\
\hline 1992 & Guidelines for Establishing Marine Protected Areas & Kelleher and Kenchington (1992) \\
\hline 1992 & Guidelines for Mountain Protected Areas & Poore (1992) \\
\hline \multicolumn{3}{|c|}{ 1992-2003 } \\
\hline 1993 & $\begin{array}{l}\text { Parks, Peaks and People: A collection of papers arising from an } \\
\text { international consultation on protected areas in mountain environments } \\
\text { held in Hawaii Volcanoes National Park } 26 \text { October - } 2 \text { November } 1991\end{array}$ & Hamilton et al. (1993) \\
\hline 1994 & Guidelines for Protected Area Management Categories & IUCN (1994a) \\
\hline 1994 & Parks for Life: Action for protected areas in Europe & IUCN (1994b) \\
\hline 1995 & African Heritage 2000 & IUCN (1995) \\
\hline 1996 & Transborder Protected Area Co-Operation & Hamilton, et al. (1996) \\
\hline 1996 & Tourism, Ecotourism and Protected Areas & Ceballos-Lascuráin (1996) \\
\hline 1997 & Guidelines for Cave and Karst Protection & Watson et al. (1997) \\
\hline 1998 & $\begin{array}{l}\text { National System Planning for Protected Areas: Best practice guideline } \\
\text { (No. 1) }\end{array}$ & Davey (1998) \\
\hline 1998 & $\begin{array}{l}\text { Economic Values of Protected Areas: Guidelines for protected area } \\
\text { managers (No. 2) }\end{array}$ & WCPA (1998) \\
\hline 1999 & The Green Web: A union for world conservation & Holdgate (1999) \\
\hline 1999 & Guidelines for Marine Protected Areas (No. 3) & Kelleher (1999) \\
\hline 1999 & $\begin{array}{l}\text { Guidelines for Public Use Measurement and Reporting at Parks and } \\
\text { Protected Areas }\end{array}$ & Hornback and Eagles (1999) \\
\hline 1999 & $\begin{array}{l}\text { Linkages in the Landscape: The role of corridors and connectivity in } \\
\text { wildlife conservation }\end{array}$ & Bennett (2003) \\
\hline 2000 & $\begin{array}{l}\text { Indigenous and Traditional Peoples and Protected Areas: Principles, } \\
\text { guidelines and case studies (No. 4) }\end{array}$ & Beltrán (2000) \\
\hline 2000 & $\begin{array}{l}\text { Financing Protected Areas: Guidelines for protected area managers (No. } \\
\text { 5) }\end{array}$ & WCPA (2000) \\
\hline 2000 & $\begin{array}{l}\text { Evaluating Effectiveness: A framework for assessing the management of } \\
\text { protected areas (No. 6) }\end{array}$ & Hockings et al. (2000) \\
\hline 2001 & Protected Area Management: Principles and practice & Worboys et al. (2001) \\
\hline
\end{tabular}




\begin{tabular}{|c|c|c|}
\hline Year & Title & Reference \\
\hline 2001 & Transboundary Protected Areas for Peace and Co-Operation (No. 7) & Sandwith et al. (2001) \\
\hline 2002 & $\begin{array}{l}\text { Sustainable Tourism in Protected Areas: Guidelines for planning and } \\
\text { management (No. 8) }\end{array}$ & Eagles et al. (2002) \\
\hline 2002 & $\begin{array}{l}\text { Management Guidelines for Category V Protected Areas: Protected } \\
\text { landscapes/seascapes (No. 9) }\end{array}$ & Phillips (2002) \\
\hline 2003 & Guidelines for Management Planning of Protected Areas (No. 10) & Thomas and Middleton (2003) \\
\hline 2003 & The Full Value of Parks: From economics to the intangible & Harmon and Putney (2003) \\
\hline \multicolumn{3}{|c|}{ 2003-14 } \\
\hline 2004 & $\begin{array}{l}\text { Integrating Biodiversity Conservation and Sustainable Use: Lessons } \\
\text { learned from ecological networks }\end{array}$ & Bennett (2004) \\
\hline 2004 & $\begin{array}{l}\text { Indigenous and Local Communities and Protected Areas: Towards equity } \\
\text { and enhanced conservation (No. 11) }\end{array}$ & Borrini-Feyerabend et al. (2004) \\
\hline 2004 & $\begin{array}{l}\text { Speaking a Common Language: The uses and performance of } \\
\text { management categories for protected areas }\end{array}$ & Bishop et al. (2004) \\
\hline 2004 & Guidelines for Planning and Managing Mountain Protected Areas & Hamilton and McMillan (2004) \\
\hline 2004 & $\begin{array}{l}\text { Managing Mountain Protected Areas: Challenges and responses for the } \\
\text { 21st century }\end{array}$ & Harmon and Worboys (2004) \\
\hline 2004 & $\begin{array}{l}\text { Securing Protected Areas in the Face of Global Change: Issues and } \\
\text { strategies }\end{array}$ & Barber et al. (2004) \\
\hline 2005 & Protected Area Management: Principles and practice (2nd edn) & Worboys et al. (2005) \\
\hline 2005 & $\begin{array}{l}\text { The Urban Imperative: Urban outreach strategies for protected area } \\
\text { agencies }\end{array}$ & Trzyna (2005) \\
\hline 2005 & $\begin{array}{l}\text { The Protected Landscape Approach: Linking nature, culture and } \\
\text { community }\end{array}$ & Brown et al. (2005) \\
\hline 2005 & $\begin{array}{l}\text { Benefits beyond Boundaries: Proceedings of the Vth IUCN World Parks } \\
\text { Congress, Durban South Africa, 8-17 September } 2003\end{array}$ & IUCN (2005) \\
\hline 2006 & $\begin{array}{l}\text { Security Considerations in the Planning and Management of } \\
\text { Transboundary Conservation Areas }\end{array}$ & Braack et al. (2006) \\
\hline 2006 & Managing Protected Areas: A global guide & Lockwood et al. (2006) \\
\hline 2006 & $\begin{array}{l}\text { Forests and Protected Areas: Guidance on the use of the IUCN protected } \\
\text { area management categories (No. 12) }\end{array}$ & Dudley and Phillips (2006) \\
\hline 2006 & $\begin{array}{l}\text { Sustainable Financing of Protected Areas: A global review of challenges } \\
\text { and options (No. 13) }\end{array}$ & Emerton et al. (2006) \\
\hline 2006 & $\begin{array}{l}\text { Evaluating Effectiveness: A framework for assessing management } \\
\text { effectiveness of protected areas (2nd edn) (No. 14) }\end{array}$ & Hockings et al. (2006) \\
\hline 2007 & Peace Parks & Ali (2007) \\
\hline 2007 & $\begin{array}{l}\text { Protected Areas and Spirituality: Proceedings of the First Workshop of the } \\
\text { Delos Initiative }\end{array}$ & Mallarach and Papayannis (2007) \\
\hline 2007 & $\begin{array}{l}\text { Identification and Gap Analysis of Key Biodiversity Areas: Targets for } \\
\text { comprehensive protected area systems (No. 15) }\end{array}$ & Langhammer et al. (2007) \\
\hline 2007 & Protected Areas: Buffering nature against climate change & Taylor and Figgis (2007) \\
\hline 2008 & Sacred Natural Sites: Guidelines for protected area managers (No. 16) & Wild and McLeod (2008) \\
\hline 2008 & $\begin{array}{l}\text { Protected Landscapes and Agrobiodiversity Values. Volume } 1 \text { in the series } \\
\text { Values of Protected Landscapes and Seascapes }\end{array}$ & Amend et al. (2008) \\
\hline 2008 & $\begin{array}{l}\text { Protected Landscapes and Cultural and Spiritual Values. Volume } 2 \text { in the } \\
\text { series Values of Protected Landscapes and Seascapes }\end{array}$ & Mallarach (2008) \\
\hline 2008 & Guidelines for Applying Protected Area Management Categories & Dudley (2008) \\
\hline 2010 & Connectivity Conservation Management: A global guide & Worboys et al. (2010) \\
\hline
\end{tabular}




\begin{tabular}{|c|c|c|}
\hline Year & Title & Reference \\
\hline 2010 & $\begin{array}{l}\text { Natural Solutions: Protected areas helping people cope with climate } \\
\text { change }\end{array}$ & Dudley et al. (2010) \\
\hline 2010 & Sacred Natural Sites: Conserving nature and culture & Verschuuren et al. (2010) \\
\hline 2010 & Arguments for Protected Areas: Multiple benefits for conservation and use & Stolton and Dudley (2010) \\
\hline 2010 & $\begin{array}{l}50 \text { Years of Working for Protected Areas: A brief history of the IUCN World } \\
\text { Commission on Protected Areas }\end{array}$ & IUCN (2010) \\
\hline 2011 & IUCN Guidelines for Protected Area Legislation & Lausche (2011) \\
\hline 2011 & $\begin{array}{l}\text { Protected Area Staff Training: Guidelines for planning and management } \\
\text { (No. 17) }\end{array}$ & Kopylova and Danilina (2011) \\
\hline 2012 & $\begin{array}{l}\text { Ecological Restoration for Protected Areas: Principles, guidelines and best } \\
\text { practices (No. 18) }\end{array}$ & Keenleyside et al. (2012) \\
\hline 2012 & $\begin{array}{l}\text { Protected Landscapes and Wild Biodiversity. Volume } 3 \text { in the series } \\
\text { Values of Protected Landscapes and Seascapes }\end{array}$ & Dudley and Stolton (2012) \\
\hline 2012 & Innovation for 21 st Century Conservation & Figgis et al. (2012) \\
\hline 2012 & Conserving Australia's Marine Environment: Key directions statement & Figgis and Koss (2012) \\
\hline 2012 & Parks relaunched as an e-journal (after a gap in publication from 2008) & Various \\
\hline 2013 & Terrestrial Biodiversity and the World Heritage List & Bertzky et al. (2013) \\
\hline 2013 & $\begin{array}{l}\text { Keeping the Outstanding Exceptional: The future of world heritage in } \\
\text { Australia }\end{array}$ & Figgis et al. (2013) \\
\hline 2013 & The Legal Aspects of Connectivity Conservation & Lausche et al. (2013) \\
\hline 2013 & Governance of Protected Areas: From understanding to action & Borrini-Feyerabend et al. (2013) \\
\hline 2014 & Urban Protected Areas - Profiles and Best Practice Guidelines & Trzyna (2014) \\
\hline 2015 & Protected Area Governance and Management & Worboys et al. (2015) \\
\hline
\end{tabular}


This text taken from Protected Area Governance and Management,

edited by Graeme L. Worboys, Michael Lockwood, Ashish Kothari, Sue Feary and Ian Pulsford, published 2015 by ANU Press, The Australian National University, Canberra, Australia.

Reproduction of this ANU Press publication for educational or other non-commercial purposes is authorised without prior written permission from the copyright holder, provided the source is fully acknowledged. Reproduction of this publication for resale or other commercial purposes is prohibited without prior written permission of the copyright holder. 